\title{
Earnings management around founder CEO reappointments and successions in family firms
}

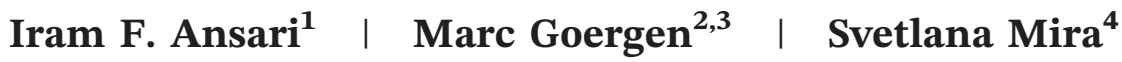

${ }^{1}$ College of Economics and Political Science, Sultan Qaboos University, Muscat, Oman

${ }^{2}$ IE Business School, IE University, Madrid, Spain

${ }^{3}$ European Corporate Governance Institute (ECGI), Brussels, Belgium

${ }^{4}$ Cardiff Business School, Cardiff

University, Cardiff, UK

\section{Correspondence}

Svetlana Mira, Cardiff Business School, Cardiff University, Aberconway Bldg.,

Colum Dr., Cardiff, CF10 3EU,

United Kingdom.

Email: MiraS@cardiff.ac.uk

\begin{abstract}
This paper studies reappointment of a chief executive officer (CEO) and succession events in listed family firms with an incumbent family CEO. We explore whether family firms with a founder CEO are more likely to engage in earnings management preevent than other family firms. We find evidence of preevent upward earnings management for firms that reappoint their founder CEO but no for other family firms. These findings suggest that the costs and benefits from earnings management change around founder CEO reappointments in family firms. Investors, auditors, policymakers and regulators should be aware of
\end{abstract}

We would like to express our thanks to John Doukas, the Editor, as well as two anonymous reviewers for their support and constructive feedback on earlier versions of our paper. We are also very grateful to Michelle Hanlon, who commented extensively on an early draft of this paper. We have benefitted from comments made by Peter Easton, participants at seminars at Cardiff Business School and the College of Economics and Political Science, Sultan Qaboos University, as well as participants at the 16th Workshop on Corporate Governance and Investment, Alliance Manchester Business School, the 2019 Annual Conference of British Accounting and Finance Association SWAG, the 2020 European Corporate Governance Institute-Stockholm School of Economics Conference on SMEs, Families and Capital Markets, and the 6th International Research Forum on Mittelstand, at the University of Mannheim. 
the temptation of founder CEOs to inflate earnings preceding their reappointment.

\section{K E Y W O R D S}

earnings management, family firms, founders, socioemotional wealth, CEO turnover, CEO successions

JEL C L AS S I F I C A T ION

G32; G34; M41

\section{1 | INTRODUCTION}

Though the literature on earnings management is extensive and mature, Burgstahler and Chuk (2017, p. 741) nevertheless identify '[a] potentially important area for future research [which] is exploration of changes over time in costs and benefits of earnings management to meet benchmarks'. Using an international sample of listed family firms from France, Germany and the United Kingdom that reappoint or replace their incumbent family chief executive officer (CEO) between 2001 and 2016, we explore earnings management 2 years before and up to 2 years after the event (i.e., the reappointment or the replacement of the incumbent family CEO). Hence, de facto our period of study spans from 1999 to 2018. We argue that the reappointment or replacement of an incumbent family CEO represents a natural breaking point where the costs and benefits of earnings management to meet benchmarks are likely to be significantly different as the family is at a crossroads facing two choices. ${ }^{1}$ First, the family can turn its firm into a firm managed by a professional nonfamily CEO, likely combined with gradual divestment by the family - or to the very least the emergence of an arm's length relationship between the family and the firm. Second, the family can maintain the status of a family firm, that is, a firm managed and monitored by successive generations of the family.

On the basis of the above, we argue that the costs and benefits of family firms to engage in earnings management change around founder CEO reappointments. Prior evidence (e.g., GómezMejía et al., 2007, 2011) show that family firms are unique entities that behave differently because of the socioemotional wealth the controlling/founder family holds in the firm. Socioemotional wealth refers to the pursuit by family firms of objectives other than purely financial objectives. Hence, we maintain that founder CEOs who opt for reappointment, given their greater socioemotional attachment to their firm than later-generation family CEOs, engage in earnings management to report good performance in the year preceding their reappointment. This ensures that the minority shareholders are less likely to oppose the family's ongoing control and management of the firm, allowing the incumbent family founder CEO to pursue their vision of the firm. Though we corroborate prior evidence that overall family firms practice less earnings management than nonfamily firms (e.g., Martin et al., 2016), we also find evidence of upward earnings management when a

\footnotetext{
${ }^{1}$ Prior studies identify other instances of natural breaking points where the controlling shareholder has incentives to manage earnings. Hou et al. (2015), for example, find that Chinese firms with a controlling shareholder entering into performance commitment contracts manages earnings upward to achieve the prespecified performance target when actual performance falls short. This suggests that, supporting the more general argument put forward by Burgstahler and Chuk (2017), firms with a controlling shareholder have incentives to use earnings management to achieve benchmarks and these incentives are only temporal.
} 
founder CEO is reappointed. More specifically, we find that actual accruals deviate from predicted accruals in the preevent year by an additional 4.8 percentage points of total assets in family firms that reappoint their founder CEO when compared to family firms that appoint a nonfamily CEO.

Following Jones (1991), Healy and Wahlen (1999), Dechow et al. (2003), Ball and Shivakumar (2005), we define accrual-based earnings management as changes made to reported earnings via discretionary accruals by the insiders to mislead certain stakeholders or to affect contractual outcomes. ${ }^{2}$ Focusing on accrual-based earnings management in family firms, and comparing different types of events in family firms, our paper makes the following four contributions to the extant literature.

First, to the best of our knowledge, this is the first study to show that the costs and benefits from earnings management change around founder CEO reappointments in family firms. We corroborate prior evidence that family firms engage in less accrual-based earnings management than nonfamily firms (Martin et al., 2016). Yet, the key and novel contribution of this study is that founder CEOs coming up for reappointment inflate earnings upwards more than other family CEOs in the year preceding their reappointment. Importantly, whereas Martin et al. (2016) find that overall founder family firms are less likely to engage in earnings management, we show the exact opposite pattern applies to founder family firms whose founder CEO is up for reappointment. ${ }^{3}$ This finding is in line with prior literature suggesting that founder firms are different from other firms when it comes to financial misconduct. For example, Andersons et al. (2017) find that the incidence of SEC enforcement actions is nearly three times greater in family firms than in matched nonfamily firms. They also document that founder CEOs account for nearly $71 \%$ of enforcement actions. Furthermore, Amiram et al. (2018) conclude that the regulators appear to under-target founder firms. In line with this evidence in the field, we show for the first time that founder CEOs in family firms inflate earnings upwards in the year preceding their reappointment. Hence, investors in family firms, as well as internal and external auditors, policymakers and regulators should be aware of the temptation of founder CEOs to engage in upward earnings management preceding their reappointment.

Second, and more generally, the paper adds to the literature on earnings management around CEO turnover, a literature, which as yet disagrees about the effects of outgoing and incoming CEOs on earnings management. We find that founder CEOs in family firms manage earnings upward in the year before coming up for reappointment more than other CEOs. Again, for the first time, we show that it is important to differentiate between the types of outgoing and incoming CEOs.

Third, to date, both the theoretical and empirical literature disagrees as to the effects of family control and ownership on earnings management. Theory predicts that there are two competing effects of concentrated ownership and control-and family ownership and control more specifically-on earnings management: the entrenchment effect and the alignment effect. According to the entrenchment effect, large shareholders-such as families-extract private benefits of control from their firm. Manipulating reported earnings is one way of extracting such benefits. Hence, earnings management should be greater and earnings quality should be

\footnotetext{
${ }^{2}$ Real earnings management is an alternative type of earnings management (e.g., Jones, 1991) and it consists of manipulating reported earnings via changing the timing and scale of various real transactions (e.g., Roychowdhury, 2006). In an earlier version of the paper, we considered both, accrual-based and real earnings management. In line with Achleitner et al. (2014), we find that family firms engage to a lesser extent in real earnings management than accrual-based earnings management yet reappointed founder CEOs inflate earnings via both types of earnings management.

${ }^{3}$ Importantly, $60 \%$ of our family firms have a founder CEO.
} 
lower in family firms. Conversely, according to the alignment effect, families reduce agency costs via their monitoring of the firm's management, which benefits all the shareholders. Families may also be keen on protecting their reputation, especially if they intend to transfer the control over the firm to future generations of the family. Our results show support for the entrenchment effect as founder CEOs who are up for reappointment engage in accrual-based earnings management.

Finally, studying three very different corporate governance systems, that is, France, Germany and the United Kingdom, rather than just a single country, increases the generalizability of our results. Given the greater levels of investor protection in the United Kingdom (Djankov et al., 2008), ${ }^{4}$ one would expect there to be less earnings management around CEO reappointments and successions than in France and Germany. We find some evidence that French and German family firms engage in more earnings management around a family CEO succession or reappointment than UK firms. This result is in line with Leuz et al. (2003) who find that earnings management is more prevalent in countries with weak investor protection. However, the results are weak from a statistical point of view and not consistent across the 2 years before and the 2 years after the event. This is not surprising given that, contrary to Leuz et al. (2003), the three countries in our sample are well-developed economies, with large stock markets and a high proportion of firms cross-listed on foreign stock exchanges associated with high investor protection.

We proceed by reviewing the two strands of literature that are directly related to earnings management around CEO reappointments and successions in family firms. The first strand is on earnings management in firms with concentrated ownership and control, including family firms, whereas the second strand is on the literature exploring the socioemotional wealth of families in their firms. To the best of our knowledge, there is as yet no study specifically investigating earnings management around CEO reappointments and successions in family firms. The literature review is followed by Section 3, which explains the sample selection and methodology. The next section discusses the results from the empirical analysis. Section 5 contains a number of robustness and additional tests. Finally, Section 6 concludes.

\section{2 | EARNINGS MANAGEMENT IN FAMILY FIRMS}

\section{1 | Earnings management in firms with concentrated ownership and control}

As stated in the introduction, theory suggests two competing effects of concentrated ownership and control-and family ownership and control more specifically-on earnings management: the entrenchment effect and the alignment effect. Whereas the entrenchment effect results in more earnings management in family firms, the alignment effect results in less. Broadly speaking, the literature is supportive of the alignment effect while evidence of the entrenchment effect tends to be limited to firms with dual-class stock. ${ }^{5}$

\footnotetext{
${ }^{4}$ France, Germany and the UK are representatives of the three main legal families (La Porta et al., 1997, 1998), that is, French civil law, German civil law and English or common law, respectively. Investor protection is strong under common law, the law of the United Kingdom, but it is weaker under French and German civil law.

${ }^{5}$ Prior studies also find that the entrenchment effect is more prominent in the founder-CEO firms than in other firms. For example, Chen et al. (2013) find that founder-CEO and descendant-CEO firms have lower turnover-performance sensitivity than professional-CEO family firms suggesting that the former two types of firms are subject to the CEO.
} 
The study by Leuz et al. (2003) is an exception to the above pattern as it finds wider support for the entrenchment effect. Their study attempts to explain differences in earnings management across 31 countries. It finds that earnings management is more prevalent in countries with relatively concentrated ownership, weak investor protection and less developed stock markets. Francis et al. (2005) as well as Martin et al. (2016) study the effect of dual-class stock on earnings management. Both studies find that the entrenchment effect is likely to be stronger the greater the deviation of cash flow rights from control rights.

Apart from Leuz et al. (2003) and the specific case of (family) firms with dual-class stock, most other studies find support for the alignment effect. Wang (2006) and Ali et al. (2007) study earnings management in S\&P 500 companies. Both studies find that family firms have lower abnormal accruals. A more recent study by Martin et al. (2016) also investigates accrual-based earnings management in US family and nonfamily firms in the S\&P 500 index. They find that family firms are less likely to manage their earnings than nonfamily firms. They also show that earnings management is lowest in founder family firms. Finally, Achleitner et al. (2014) investigate earnings management in German family and nonfamily firms. They find that family firms are less likely to engage in real earnings management whereas nonfamily firms manage earnings via accrual as well as real earnings management.

\subsection{Founder CEOs, socioemotional wealth and earnings management}

Socioemotional wealth refers to the pursuit by family firms of objectives other than purely financial objectives (see e.g., Cruz et al., 2011; Gómez-Mejía et al., 2007, 2011; Martin et al., 2016). Gómez-Mejía et al. (2007) argue that families are willing to take risks to preserve their socioemotional wealth. If this socioemotional wealth in the firm is considerable, families may be willing to engage in significant risk to preserve this wealth. Importantly, Martin et al. (2016, p. 457) argue that the emotional attachment to the firm is much stronger for founders than for their descendants as 'they have toiled to launch and develop the firm'.

For example, Dechow et al. (1996) report that founders are more likely to engage in financial manipulation. More recent evidence based on US data is somewhat at odds. Martin et al. (2016) find that abnormal accruals are lower in both family firms and founder firms (i.e., firms in which the founder is still involved), which they attribute to a positive influence of socioemotional wealth on the desire to maintain family and founder reputation. In contrast, Anderson et al. (2017), using a matched sample of family and nonfamily firms from 1978 to 2013, find that the incidence of SEC enforcement actions is nearly three times greater in family firms. They also document that founder CEOs account for nearly $71 \%$ of enforcement actions. Moreover, they use unexpected founder and nonfounder CEO deaths as an exogenous shock and perform difference-in-difference tests to show that the likelihood of accounting manipulation declines significantly following the death of the founder CEO.

Combining this evidence, we argue that founder CEOs hold a significant amount of socioemotional wealth in their firms and, in general, they will not engage in financial activities which could harm the firm. However, there is a breaking point where the incentives of founder CEOs change substantially. Founder CEO reappointments and successions represent such a point or event where the incentives of the founder CEOs to engage in earnings management exceed the costs. We argue that founder CEOs who are up for reappointment and intend on remaining as the $\mathrm{CEO}$ are more likely to engage in earnings management to improve net 
earnings in the year(s) preceding the reappointment. The reasons are as follows. First, given the socioemotional attachment founder CEOs have to their firms, they aspire to maintain the CEO position and consequently they continue to be the main decision-maker in the firm, thereby protecting the wealth of the family. Second, reporting low earnings may increase pressure from minority shareholders for the founder CEO to step down and appoint a successor, ideally a professional, nonfamily manager who may improve the firm's performance. Finally, founder CEOs intent on being reappointed are likely to have in mind major projects enhancing the future success of the firm, which require their continuation in their position as CEO. In other words, their ongoing emotional and economic investment in the firm is such that having to step down as CEO would result in a major loss to their investment. Hence, they are keen on reducing that probability. This leads us to our main hypothesis:

Hypothesis: Founder CEOs who are up for reappointment are more likely to use upward earnings management to ensure support for their reappointment.

\section{3 | SAMPLE SELECTION AND METHODOLOGY}

\section{1 | Sample selection and data sources}

Appendix 1 provides details on the sample selection. We start with the full population of domestic firms (including active, dead and suspended firms) listed in France, Germany and the United Kingdom between 2001 and 2016, which comprises 2,679 French firms, 2,352 German firms and 7,747 UK firms. As we study earnings management 2 years around the event, effectively our sample spans from 1999 to 2018. We then apply a series of filters. First, all financial firms with a Datastream Industry Classification Benchmark (ICB) code 8000 are excluded, because they follow different reporting conventions, which make comparisons with nonfinancial firms difficult. They are also subject to additional governance and reporting requirements. Second, following prior studies (e.g., Achleitner et al., 2014), we exclude firms that have only their preference shares listed and held by outsiders. As the holders of the preference shares have no voting rights but have the right to a fixed guaranteed dividend-typically a percentage of the nominal share value-they are less likely to be concerned and influenced by reported earnings. ${ }^{6}$ Third, given that all the measures of earnings management used in this paper necessitate data on total assets, we require that each firm has such data for at least 1 year during the 2001-2016 period. The remaining sample includes 1,384 French firms, 1,269 German firms and 3,568 UK firms. This sample of family and nonfamily firms is then used to estimate earnings management following the procedure detailed in Section 3.2.

Next, given the aim of the study, we distinguish between family and nonfamily firms. Following Ansari et al. (2014), a family firm is defined as a firm with a family CEO as well as with the family owning at least $25 \%$ of the votes and remaining the largest shareholder for at least half of the period of the study. A CEO is considered to be a family CEO if the CEO is the founder or a descendant of the founder, the CEO's surname is identical to the firm's name, or he/she shares his/her surname with another member of the firm's board of directors. In case of pyramidal ownership, the ultimate

\footnotetext{
${ }^{6}$ However, note that we still include firms with dual-class shares where both classes are listed. There are 45 such firms in our sample of which one firm is from France, none from Germany and 44 in the United Kingdom. We include such firms as some of the ordinary shares will be in the hands of minority shareholders who will be concerned about reported earnings.
} 
owners were identified to calculate the total votes they hold. Hence, our sample of family firms is relatively small by construction as we require the incumbent CEO to be a family member. ${ }^{7}$ By definition, founder and nonfounder CEOs in our sample hold at least $25 \%$ of the votes in the company. The latter three selection criteria result in 187 French, 120 German and 87 UK family firms. Fifth, given the focus of this paper, we retain only those family firms in the sample with at least one event, that is, one change in the CEO or at least one reappointment of the incumbent CEO between 2001 and $2016 .^{8}$ Finally, we drop seven firms from the sample without a clear-cut event date. ${ }^{9}$ The final sample comprises 240 family firms, of which 122 are French, 76 are German and 42 are UK firms. As some firms replace or reappoint their CEO more than once during our research period, the final sample covers 306 events, that is, CEO successions as well as reappointments (152 French, 95 German and 59 UK events). Out of these 306 events, there are 182 events in the sample where the founder is up for reappointment or replacement.

The reader should also note that only six of the 306 events relate to the death of the CEO and only one of these events relates to the death of a founder CEO. Hence, we are not in a position to use unexpected founder CEO deaths as an exogenous shock (Anderson et al., 2017) to test the likelihood of an earnings manipulation decline after the death of the founder CEO.

The corporate governance characteristics for the sample firms and the biographies of the incumbent CEOs as well as the successor CEOs are collected from the company reports, Reuters, Thomson One Banker, company websites and country-specific company guides. ${ }^{10}$ LexisNexis, various newspaper archives, Forbes and Capital IQ are used to identify the event date. Financial information is sourced from Datastream and Osiris.

\subsection{Definitions of the variables and models}

\section{Types of events}

We distinguish between four types of events: (a) Founder reappointments; (b) appointments of nonfamily CEOs; (c) appointments of new family CEOs; and (d) other reappointments, that is, reappointments of nonfounder family CEOs. Appointments of nonfamily CEOs, as well as new family CEOs, are actual CEO changes or successions whereas founder reappointments and other reappointments maintain the status quo. A reappointment is defined as the appointment of the incumbent family CEO for another term. ${ }^{11}$ If the incumbent family CEO is not

\footnotetext{
$\overline{7}$ Broadening our definition of a family firm and including family firms without an incumbent family CEO would reduce the focus of the paper.

${ }^{8} \mathrm{~A}$ reappointment is defined as the appointment of the incumbent family CEO to office for a further period of time. As stated in the Supporting Information Appendix A, the renewed length of the term of the CEO may be one of the following: (1) specifically fixed by the firm (as stated in the initial public offering (IPO) prospectus or annual report), or (2) based on the country-specific governance regulation on maximum CEO term, which is 6 years in the case of France, 5 years for Germany, and 3 years for the United Kingdom.

${ }^{9}$ Comparing the identity of the CEO stated in the annual reports from 1 year to another, we know that there was a change in the CEO in a particular year, but we are unable to identify the exact date of the succession.

${ }^{10}$ In addition, we use Hoppenstedt Aktienführer for Germany and Companies Handbooks for the United Kingdom.

${ }^{11}$ 'Another term' is specific to the firm and may be equivalent to the period recommended in the country's respective governance code or shorter. Supporting Information Appendix A provides a description of the legal and institutional framework pertaining to reappointments in France, Germany and the United Kingdom. It also discusses the criteria met by all the reappointments included in the sample. This description suggests that the reappointments are genuine reelections of the incumbent $\mathrm{CEO}$ rather than just the rubberstamping of the extension of their term.
} 
reappointed, then there are two alternative succession options: Appointing a nonfamily CEO or appointing a new family CEO. ${ }^{12}$

Following Choi et al. (2014), we define year 0 as the event year, that is, the first full fiscal year during which the incumbent CEO (assuming the incumbent was not reappointed) is no longer in office. We require the new CEO to be in office during the first quarter of that year. If this is not the case, the next year is then treated as year 0. By implication, year -1 is the last fiscal year when the incumbent CEO is in office throughout the entire year. In case of reappointments, year 0 is the fiscal year following the fiscal year of the reappointment date.

\section{Measurement of earnings management}

Our measure of accrual-based earnings management is based on Ball and Shivakumar's (2005) $)^{13,14}$ and Wang's (2006) modifications of Dechow and Dichev (2002). This model is the nonlinear version of the traditional, linear model by Jones (1991). The main advantage of the nonlinear model is its greater explanatory power (Ball \& Shivakumar, 2005; Wang, 2006). ${ }^{15}$ The approach adopted to measure accruals is similar to that used in extant literature. Accruals are determined by estimating the following equation:

$$
\mathrm{ACC}_{t}=\alpha_{0}+\alpha_{1} \mathrm{CF}_{t}+\alpha_{2} \mathrm{CF}_{t-1}+\alpha_{3} \mathrm{CF}_{t+1}+\alpha_{4} \mathrm{DCF}_{t}+\alpha_{5} \mathrm{DCF}_{t} * \mathrm{CF}_{t}+\varepsilon t
$$

where $\mathrm{ACC}_{t}$ is total accruals at year $t$, scaled by total assets at $t-1 ; \mathrm{CF}_{t}$ is cash flow from operations at $t$ scaled by total assets at $t-1 ; \mathrm{DCF}_{t}$ equals one if the cash flow from operations at $t$ is negative, and zero otherwise; $\mathrm{DCF}_{t} \times \mathrm{CF}_{t}$ is the proxy for economic losses; $\varepsilon_{t}$ is an error term.

Equation (1) includes a proxy for economic losses as it is likely that such losses are recognized in a timelier manner, as unrealized charges against income, whereas economic gains are more likely to be recognized only once realized as charges against cash flow (see Ball \& Shivakumar, 2005). Importantly, Equation (1) is estimated on the entire population of French, German and UK firms. Hence, our benchmark of what constitutes normal levels of accruals should not be biased by earnings management practices unique to family firms and it should reflect earnings practices across both family and nonfamily firms.

Supporting Information Appendix B shows that 30 out of the 36 firms with repeated reappointments took place three or more years after the previous event.

${ }^{12}$ A new family CEO consists of a family member of the incumbent CEO succeeding him/her. A family member may include the spouse, child, sibling, cousin or in-law. The family relations of the family CEOs are confirmed through the IPO prospectuses. A nonfamily CEO is a person not related (by blood/marriage or other ties) to the incumbent family CEO who succeeds him/her.

${ }^{13}$ Adapted from the model of Dechow et al. (1998) to incorporate the recognition of unrealised gains and losses via accruals.

${ }^{14} \mathrm{~A}$ vast literature emerged following the work of Hayn (1995) using the so-called 'discontinuities' in earnings distribution around zero as a measure of earnings management. However, subsequent studies (see e.g., Dechow et al. 2003; Durtschi \& Easton 2009) show that this 'kink' in the earnings distribution is likely caused by factors other than earnings management. Hence, we disregard this approach.

${ }^{15}$ Accounting income is likely to be nonlinear as it is generated by two different processes. The first one is a moving average of current and past economic gains and the second one is a more transitory, that is, less smoothed, incorporation of economic losses (Ball \& Shivakumar, 2005). 
More precisely, as in Ball and Shivakumar (2005), Equation (1) is estimated by country, industry and year, requiring a minimum of 30 observations. For this purpose, we use ICB from Datastream. The country-, industry- and year-specific parameter estimates are then used to obtain the normal discretionary accruals for each firm-year observation. The abnormal accruals, proxying for accrualbased earnings management, are the residuals obtained from that equation. We then estimate the following ordinary least squares (OLS) regression model, with heteroskedasticity-consistent standard errors clustered at the firm level, to test our main hypothesis.

$$
\begin{aligned}
& \text { EARNINGS MANAGEMENT }_{i t}=\pi_{0}+\pi_{1} \text { EVENT TYPE }_{i} \\
& +\pi_{2} \text { FAMILY WEDGE }_{i,-1}+\pi_{3} \text { BOARD INDEPENDENCE }_{i,-1}+\pi_{4} \text { DUALITY }_{i,-1} \\
& +\pi_{5} \text { DUALITY-DESTROYING EVENT }{ }_{i} \\
& +\pi_{6} \text { DEPARTING FOUNDER CEO ON BOARD POSTEVENT } T_{i}+\pi_{7} \operatorname{lnTA}_{i t} \\
& +\pi_{8} \mathrm{ROA}_{i t}+\pi_{9} \text { LEVERAGE }_{i t}+\pi_{10} \text { BOOK-TO-MARKET }_{i t}+\pi_{11} \text { LOSS }_{i t} \\
& +\pi_{12} \text { BIG FOUR }_{i t}+\text { COUNTRY DUMMIES }+ \text { TIME DUMMIES } \\
& + \text { INDUSTRY DUMMIES }+\mu_{t}, t=-2,-1, \ldots+2 \text {, }
\end{aligned}
$$

where EARNINGS MANAGEMENT ${ }_{t}$ is the accrual-based earnings management as defined in Equation (1) above; EVENT TYPE $i$ is one of the dummy variables indicating the event type(s), such as nonfamily CEO appointments, new family CEO appointments and other reappointments; FAMILY WEDGE $E_{i,-1}$ equals one if the difference between family control and family ownership in year -1 is different from 0 , and zero otherwise ${ }^{16}$; BOARD INDEPENDENCE $E_{i,-1}$ is the proportion of nonexecutive directors on the board as reported in the annual report for year $-1{ }^{17}$; DUALITY DU, $_{i}$ equals one if the CEO also acts as the chair of the board in year -1 , and zero otherwise $^{18}$; DUALITY-DESTROYING EVENT ${ }_{i}$ equals one if there is CEO-chair duality in year -1 but it disappears in year 0, and zero otherwise. DEPARTING FOUNDER CEO ON BOARD POST$\mathrm{EVENT}_{i}$ equals one if the departing founder CEO is still on the board of directors in year 0 , and zero otherwise $^{19} ; \operatorname{lnTA}_{t}$ is the natural logarithm of total assets at $t ; \mathrm{ROA}_{t}$ is the return on assets at $t$; LEVERAGE $_{t}$ is debt over total assets at $t$; BOOK-TO-MARKET ${ }_{t}$ is the book value of equity divided by the market value of equity at $t$. LOSS $t$ equals one if net income is negative, and zero otherwise. BIG FOUR $t$ is one if the auditor belongs to one of the top four audit firms in year $t$, and zero otherwise; and $\mu_{t}$ is an error term.

Six of the above variables control for the entrenchment effect on earnings management. They are family wedge (which would adjust for the presence of dual-class shares, including the proportion of nonvoting shares), board independence, CEO-chair duality, duality-destroying event, and departing founder $\mathrm{CEO}$ on board postevent. We expect that the higher these

\footnotetext{
${ }^{16}$ When we use a continuous measure of the family wedge, our main results are upheld.

${ }^{17}$ For all German and French firms with a two-tier board, board independence is based on the shareholder representatives, excluding any directors representing employees. Board size is defined as the sum of the number of shareholder representatives on the supervisory board and the board size of the management board, the latter being composed of executives only.

${ }^{18}$ German company law (paragraph 105, AktG) prevents duality (see e.g., Goergen et al., 2015).

${ }^{19}$ For German and French firms with two boards, this would consist of the departing CEO moving to the supervisory board. An earlier version of the paper included a dummy variable named departing CEO on the board in year 0 , that is, a dummy variable focusing not just on founder CEOs. The results were not materially different with the inclusion of this alternative variable.
} 
variables, that is, the greater the private benefits of control, the greater is the earnings management around the founder CEO reappointments.

\section{4 | EMPIRICAL ANALYSIS}

\section{1 | Descriptive statistics}

Panel A of Table 1 reports the distribution of the firms across the three countries. The majority of family firms in our sample are from France which reflects the relatively greater concentration of control, including family control in France. The total number of events in the 240 firms is 306 . Out of the 240 firms, 190 firms are involved in one event during the period of study, 38 are involved in

TABLE 1 Country distribution of the 306 events in 240 family firms

This table reports in Panel A, the distribution across countries of the 306 events in 240 firms. In Panel B, the distribution across industries is reported. The reported numbers related to the number of firms are based on the first event for the firm during the period of study and are measured in the year before the event (i.e., year -1). Out of the 240 firms, 190 firms are involved in one event, 38 are involved in two events during the period of study, nine firms in three events, two firms in four events and one firm in five events.

\begin{tabular}{|c|c|c|c|c|c|c|}
\hline \multicolumn{7}{|c|}{ Panel A: Country distribution } \\
\hline \multirow[b]{2}{*}{ Country } & \multicolumn{5}{|l|}{ Events } & \multirow[b]{2}{*}{ Firms } \\
\hline & $\begin{array}{l}\text { Founder } \\
\text { reappointments }\end{array}$ & $\begin{array}{l}\text { Nonfamily } \\
\text { successor }\end{array}$ & $\begin{array}{l}\text { New family } \\
\text { successor }\end{array}$ & $\begin{array}{l}\text { Other } \\
\text { reappointments }\end{array}$ & $\begin{array}{l}\text { Total } \\
\text { events }\end{array}$ & \\
\hline France & 66 & 28 & 27 & 31 & 152 & 122 \\
\hline Germany & 44 & 29 & 7 & 15 & 95 & 76 \\
\hline $\begin{array}{l}\text { United } \\
\text { Kingd }\end{array}$ & 24 & 16 & 7 & 12 & 59 & 42 \\
\hline Total & 134 & 73 & 41 & 58 & 306 & 240 \\
\hline \multicolumn{7}{|c|}{ Panel B: Industry distribution } \\
\hline & & \multicolumn{2}{|l|}{ Firms } & \multicolumn{3}{|l|}{ Percent } \\
\hline \multicolumn{2}{|c|}{ 1. Oil \& Gas } & \multicolumn{2}{|l|}{4} & \multicolumn{3}{|l|}{1.7} \\
\hline \multicolumn{2}{|c|}{ 2. Basic Materials } & \multicolumn{2}{|l|}{11} & \multicolumn{3}{|l|}{4.6} \\
\hline \multicolumn{2}{|c|}{ 3. Industrials } & \multicolumn{2}{|l|}{63} & \multicolumn{3}{|l|}{26.2} \\
\hline \multicolumn{2}{|c|}{ 4. Consumer Goods } & \multicolumn{2}{|l|}{48} & \multicolumn{3}{|l|}{20.0} \\
\hline \multicolumn{2}{|c|}{ 5. Health Care } & \multicolumn{2}{|l|}{10} & \multicolumn{3}{|l|}{4.2} \\
\hline \multicolumn{2}{|c|}{ 6. Consumer Services } & \multicolumn{2}{|l|}{43} & \multicolumn{3}{|l|}{17.9} \\
\hline \multicolumn{2}{|c|}{ 7. Telecommunications } & \multicolumn{2}{|l|}{1} & \multicolumn{3}{|l|}{0.4} \\
\hline \multicolumn{2}{|c|}{ 8. Utilities } & \multicolumn{2}{|l|}{1} & \multicolumn{3}{|l|}{0.4} \\
\hline \multicolumn{2}{|c|}{ 9. Technology } & \multicolumn{2}{|l|}{59} & \multicolumn{3}{|l|}{24.6} \\
\hline \multicolumn{2}{|l|}{ Total } & \multicolumn{2}{|l|}{240} & 100.0 & & \\
\hline
\end{tabular}


TABLE 2 Summary statistics for the 240 firms

This table reports the summary statistics for the 240 firms. The reported numbers are based on the first event for the firm during the period of the study and are measured in the year before the event (i.e., year -1 ). Return on assets (ROA), leverage and book-to-market are winsorized at the 2nd and the 98th percentiles. Thirty-eight out of the 240 firms are involved in two events during the period of study, nine firms in three events, two firms in four events and one firm in five events.

\begin{tabular}{|lllllc|} 
& Mean & Median & SD & Minimum & Maximum \\
\hline Founder CEO & 0.607 & 1.000 & 0.490 & 0.000 & 1.000 \\
\hline Founder reappointments & 0.408 & 0.000 & 0.493 & 0.000 & 1.000 \\
\hline Departing founder CEO on board postevent & 0.162 & 0.000 & 0.370 & 0.000 & 1.000 \\
\hline Total assets, EUR billions & 0.624 & 0.082 & 3.284 & 0.002 & 42.142 \\
\hline Family wedge dummy & 0.423 & 0.000 & 0.495 & 0.000 & 1.000 \\
\hline Family control & 0.602 & 0.604 & 0.158 & 0.257 & 0.994 \\
\hline Family ownership & 0.540 & 0.543 & 0.156 & 0.177 & 0.994 \\
\hline Board independence & 0.535 & 0.550 & 0.167 & 0.000 & 0.933 \\
\hline Duality & 0.471 & 0.000 & 0.500 & 0.000 & 1.000 \\
\hline Duality-destroying event & 0.129 & 0.000 & 0.336 & 0.000 & 1.000 \\
\hline ROA & 0.096 & 0.107 & 0.142 & -1.060 & 0.360 \\
\hline Loss & 0.223 & 0.000 & 0.417 & 0.000 & 1.000 \\
\hline Leverage & 0.179 & 0.139 & 0.163 & 0.000 & 0.623 \\
\hline Book-to-market & 0.852 & 0.707 & 0.661 & -0.546 & 3.291 \\
\hline Big Four & 0.481 & 0.000 & 0.501 & 0.000 & 1.000 \\
\hline
\end{tabular}

two events, nine firms in three events, two firms in four events and one firm in five events (not tabulated). The most frequent type of event in the family firms is founder reappointments, followed by the replacement of the family CEO by a nonfamily CEO. Across the three countries, the only slight exception to this rule is France where the second most important type of event is the reappointment of the nonfounder family $\mathrm{CEO} .{ }^{20}$ Panel B of Table 2 reports the distribution of the 240 family firms across industries. About $26 \%$ of our sample firms are in Industrials and $25 \%$ in Technology, followed by $20 \%$ of firms in Consumer Goods.

Table 2 reports descriptive statistics for year -1 for the 240 family firms included in the sample. About $61 \%$ of the firms have a founder CEO. This percentage varies from only $53 \%$ in the United Kingdom to 68\% in Germany, with France being in between with 59\% (not tabulated). Given the purpose of our study, it is worth noting that the departing founder CEO remains on the board of directors of the family firm in year 0 in $16 \%$ of the firms. Untabulated results show this percentage ranges from 16 for France and Germany to 19 for the United Kingdom. The table also suggests that the family firms are relatively small. The average market value is approximately $€ 624$ million

\footnotetext{
${ }^{20}$ Untabulated results show that the median firm age in year 0 is 25.5 years for the French firms, 22 years for the German firms and 21 for the UK firms. The median differences are not statistically significant across the three countries.
} 
whereas the median value is only $€ 82$ million. This compares to an average of $€ 2.70$ billion for the entire population of listed firms in France, Germany and the United Kingdom during the period of study (not tabulated). Though a sizeable percentage of family firms (about 42\%) have a wedge between the percentage of votes (control) and the percentage of cash flow rights (ownership) held by the family shareholder, the average wedge is only $6.4 \%$ (not tabulated). The majority, that is, 134 firms out of the 240 firms in the sample (i.e., about 56\%) have a wedge equal to or below zero. ${ }^{21}$ When these firms are excluded, the mean value of the wedge increases to $14.0 \%$ (not tabulated). As one would expect, both family control and family ownership are highly concentrated and exceed a simple majority in the average and median firm. Untabulated results also show that the median family control is higher for the nonfounder firms than for the founder firms, amounting to $63.6 \%$ and $58.1 \%$, respectively. On average, slightly more than half of the board seats are taken up by nonexecutive directors. Almost half of the family firms have CEO-chair duality. Though German company law prohibits duality, $79 \%$ of the French firms have CEO-chair duality compared to $40 \%$ of the UK firms (not tabulated). In line with previous literature (e.g., Andres, 2008), the family firms are relatively old with an average (median) age of about 44 years (25 years). The average firm is relatively profitable as evidenced by a return on assets (ROA) of 9.6\%. However, as it is frequently the case for accounting variables there is great variability in ROA, with the minimum being as low as $-106.0 \%$ and the maximum being $36.0 \%{ }^{22}$ Nevertheless, the percentage of firms with negative net income is relatively high with $22.3 \%$. Leverage tends to be low with an average of $17.9 \%$. Finally, $48 \%$ of the sample firms are audited by a Big Four audit firm.

\section{2 | Regression analysis}

In what follows, we estimate a number of OLS regressions to test the validity of our main hypothesis that founder CEOs who get reappointed are more likely to manage their firm's earnings in the year preceding their reappointment. Before proceeding with the main test, it is worth noting that we corroborate prior evidence using an extended sample of both family and nonfamily firms. ${ }^{23}$ Indeed, untabulated regression results show that family firms are less likely to manage earnings than nonfamily firms. The family firm dummy, which takes a value of one for family firms and zero for nonfamily firms, is negative and significant in all 5 years, except for year -1 when it is insignificant. This suggests that family firms behave differently in the year preceding the reappointment or the succession of the family CEO. Further untabulated results show that the latter evidence is driven by the reappointed founder CEOs. Hence, similar to extant research (e.g., Martin et al., 2016), we find that overall family firms are less likely to use earnings management than nonfamily firms. However, we show for the first time that family firms are no different from nonfamily firms in year -1 , except for the family firms that reappoint their founder CEOs. Our results suggest that reappointed founder CEOs are more likely to manage their earnings upwards in year -1 than nonfamily firms.

Next, we return the focus to family firms. Prior evidence (e.g., Gómez-Mejía et al., 2007; Martin et al., 2016) shows that family CEOs hold a significant amount of socio-emotional

\footnotetext{
${ }^{21}$ There are only seven firms with a negative wedge.

${ }^{22} \mathrm{ROA}$, leverage and book-to-market reported in Table 2 are winsorized at the 2 nd and the 98th percentiles.

${ }^{23}$ In detail, we test the hypothesis that family firms engage in less earnings management than nonfamily firms using a sample of 613 firms of which 240 are family firms and 373 are nonfamily firms. All these firms have at least one event, that is, one change in the CEO or at least one reappointment of the incumbent CEO during 2001 and 2016.
} 
TABLE 3 Comparing earnings management around founder CEO reappointments and nonfamily CEO appointments

This table reports the ordinary least square regressions for accrual-based earnings management on the nonfamily CEO dummy, the measures of private benefits of control as well as a set of control variables measured in year $t$. It focuses on 207 events in family firms of which 134 are founder CEO reappointments and 73 are nonfamily CEO appointments. The regressions compare nonfamily CEO appointments with founder CEO reappointments. The nonfamily CEO appointment dummy takes a value of one if a nonfamily CEO is appointed, and zero otherwise. The five measures of private benefits of control are: the family wedge dummy, board independence, duality, duality-destroying event and departing founder CEO on board postevent. The control variables, except for the loss dummy, Big Four, country and year dummies, are winsorized at the 2nd and the 98 th percentiles. Year 0 is the event year, that is, the first full fiscal year during which the incumbent CEO is no longer in office. In case of reappointments, year 0 is the fiscal year following the fiscal year of the reappointment date. The $t$ values presented in parentheses are heteroscedasticity consistent and the standard errors are clustered by firm. *, ** and *** stand for statistical significance at the $10 \%, 5 \%$ and $1 \%$ level, respectively.

\begin{tabular}{|c|c|c|c|c|c|}
\hline & Year -2 & Year -1 & Year 0 & Year 1 & Year 2 \\
\hline \multirow[t]{2}{*}{ Nonfamily CEO } & $-0.044^{* * *}$ & $-0.048^{* * *}$ & 0.001 & 0.012 & -0.017 \\
\hline & $(-2.89)$ & $(-2.73)$ & $(0.08)$ & $(0.78)$ & $(-0.73)$ \\
\hline \multicolumn{6}{|l|}{ Private benefits of control } \\
\hline \multirow[t]{2}{*}{ Family wedge dummy } & 0.016 & -0.009 & -0.009 & -0.007 & 0.003 \\
\hline & $(0.92)$ & $(-0.44)$ & $(-0.62)$ & $(-0.43)$ & $(0.22)$ \\
\hline \multirow[t]{2}{*}{ Board independence } & -0.038 & 0.002 & -0.012 & $-0.069 *$ & $-0.070^{* *}$ \\
\hline & $(-1.14)$ & $(0.06)$ & $(-0.33)$ & $(-1.67)$ & $(-2.05)$ \\
\hline \multirow[t]{2}{*}{ Duality } & -0.028 & -0.014 & 0.004 & 0.001 & -0.029 \\
\hline & $(-1.37)$ & $(-0.70)$ & $(0.23)$ & $(0.03)$ & $(-1.50)$ \\
\hline \multirow[t]{2}{*}{ Duality-destroying event } & $0.069^{* * *}$ & $0.064^{* * *}$ & 0.032 & -0.025 & 0.023 \\
\hline & $(2.62)$ & $(2.77)$ & $(1.31)$ & $(-0.84)$ & $(0.83)$ \\
\hline \multirow{2}{*}{$\begin{array}{l}\text { Departing founder CEO remains on board } \\
\text { postevent }\end{array}$} & & & -0.013 & 0.013 & -0.023 \\
\hline & & & $(-0.64)$ & $(0.52)$ & $(-0.85)$ \\
\hline \multicolumn{6}{|l|}{ Control variables } \\
\hline \multirow[t]{2}{*}{$\operatorname{Ln}$ (total assets) } & 0.001 & 0.002 & -0.003 & -0.001 & -0.001 \\
\hline & $(0.29)$ & $(0.40)$ & $(-0.66)$ & $(-0.33)$ & $(-0.31)$ \\
\hline \multirow[t]{2}{*}{ Return on assets } & $0.124^{* *}$ & -0.010 & $0.188^{* *}$ & $0.222^{* * *}$ & $0.167^{* *}$ \\
\hline & $(2.43)$ & $(-0.11)$ & $(2.45)$ & $(4.15)$ & $(2.23)$ \\
\hline \multirow[t]{2}{*}{ Total debt/total assets } & -0.001 & $-0.115^{* *}$ & 0.007 & $0.117^{* * *}$ & -0.073 \\
\hline & $(-0.03)$ & $(-2.58)$ & $(0.14)$ & $(2.73)$ & $(-1.46)$ \\
\hline \multirow[t]{2}{*}{ Book-to-market } & 0.003 & $-0.019^{*}$ & -0.014 & 0.001 & 0.005 \\
\hline & $(0.43)$ & $(-1.81)$ & $(-1.27)$ & $(0.08)$ & $(0.49)$ \\
\hline \multirow[t]{2}{*}{ Loss } & $-0.083^{* * *}$ & $-0.082^{* * *}$ & $-0.054^{* * *}$ & -0.033 & $-0.038^{*}$ \\
\hline & $(-4.21)$ & $(-3.84)$ & $(-2.64)$ & $(-1.42)$ & $(-1.76)$ \\
\hline
\end{tabular}


TABLE 3 (Continued)

\begin{tabular}{llllll} 
& Year -2 & Year -1 & Year 0 & Year 1 & Year 2 \\
\hline Big Four & -0.014 & $-0.021^{*}$ & -0.021 & -0.012 & 0.001 \\
& $(-1.08)$ & $(-1.67)$ & $(-1.55)$ & $(-1.03)$ & $(0.04)$ \\
France & -0.002 & 0.014 & $0.032^{*}$ & 0.007 & 0.015 \\
& $(-0.09)$ & $(0.68)$ & $(1.69)$ & $(0.35)$ & $(0.74)$ \\
Germany & -0.009 & 0.010 & $0.035^{*}$ & -0.014 & -0.001 \\
& $(-0.47)$ & $(0.55)$ & $(1.69)$ & $(-0.75)$ & $(-0.04)$ \\
Year and industry dummies & Yes & Yes & Yes & Yes & Yes \\
Constant & 0.087 & -0.024 & 0.102 & -0.002 & $0.146^{* *}$ \\
& $(1.44)$ & $(-0.42)$ & $(1.32)$ & $(-0.02)$ & $(2.13)$ \\
\hline No. of observations & 155 & 174 & 175 & 174 & 177 \\
\hline Adj. $R^{2}$ & 0.325 & 0.246 & 0.239 & 0.185 & 0.162 \\
\hline
\end{tabular}

wealth in their firms which affects their risk-taking behaviour. In what follows, we compare founder CEO reappointments, that is, the base case, consecutively with nonfamily CEO appointments, new family CEO appointments, and finally with other reappointments in Tables 3 , 4 and 5, respectively. Table 3 shows that there is strong evidence (at the $1 \%$ level of significance) of earnings management in both years -2 and -1 for firms reappointing their founder CEO compared to those appointing a nonfamily CEO. In particular, our results suggest that accrualbased earnings in year -1 increase by 4.8 percentage points of total assets if the founder CEO is reappointed. Overall, this suggests that reappointed founder CEOs engage in upward earnings management preevent. We find support for our hypothesis.

However, when founder CEO reappointments are compared with appointments of new family CEOs (see Table 4) and other reappointments (see Table 5), we do not find support for our hypothesis that founder CEOs who are up for reappointment engage in upward earnings management. Hence, the type of events in family firms matters and, in terms of earnings management, there is no difference between the founder CEO reappointments on the one side and new family CEO appointments or other reappointments on the other side. It is also worth noting that the regression coefficients on the nonfamily CEO dummy, new family CEO dummy and other reappointments reported in Tables 3-5 are all insignificant postevent (i.e., in years 0 , +1 and +2 ). This suggests that reappointed founder CEOs stop engaging in earnings management after their reappointment.

To sum up our main results, in line with extant literature, we find that family firms in general are less likely to manage their earnings than nonfamily firms. However, this behaviour changes before the reappointment of founder CEOs. As evidenced by Table 3, the key and novel contribution of this study is that family firms that reappoint their founder CEO manage their earnings upwards in the year preceding the reappointment compared to nonfamily CEO appointments. This however is not the case when we compare founder CEO reappointments with new family CEO and other reappointments. 
TABLE 4 Comparing earnings management around founder CEO reappointments and new family CEO appointments

This table reports the ordinary least square regressions for accrual-based earnings management on the new family CEO dummy, the measures of private benefits of control as well as a set of control variables measured in year $t$. It focuses on 175 events in family firms of which 134 are founder CEO reappointments and 41 are new family CEO appointments. The regressions compare new family CEO appointments with founder CEO reappointments. The new family $\mathrm{CEO}$ is set to one if a new family CEO is appointed, and zero otherwise. The five measures of private benefits of control are: the family wedge dummy, board independence, duality, dualitydestroying event and departing founder CEO on board postevent. The control variables, except for the loss dummy, Big Four, country and year dummies, are winsorized at the 2 nd and the 98 th percentiles. Year 0 is the event year, that is, the first full fiscal year during which the incumbent CEO is no longer in office. In case of reappointments, year 0 is the fiscal year following the fiscal year of the reappointment date. The $t$ values presented in parentheses are heteroscedasticity consistent and the standard errors are clustered by firm. *, ** and *** stand for statistical significance at the $10 \%, 5 \%$ and $1 \%$ level, respectively.

\begin{tabular}{|c|c|c|c|c|c|}
\hline & Year -2 & Year -1 & Year 0 & Year 1 & Year 2 \\
\hline \multirow[t]{2}{*}{ New family CEO } & 0.008 & 0.010 & 0.006 & -0.003 & -0.033 \\
\hline & $(0.41)$ & $(0.46)$ & $(0.27)$ & $(-0.14)$ & $(-1.59)$ \\
\hline \multicolumn{6}{|l|}{ Private benefits of control } \\
\hline \multirow[t]{2}{*}{ Family wedge dummy } & 0.014 & 0.002 & -0.006 & 0.006 & 0.016 \\
\hline & $(0.83)$ & $(0.10)$ & $(-0.34)$ & $(0.41)$ & $(1.11)$ \\
\hline \multirow[t]{2}{*}{ Board independence } & -0.028 & -0.011 & -0.014 & $-0.079^{*}$ & $-0.109^{* * *}$ \\
\hline & $(-0.71)$ & $(-0.34)$ & $(-0.35)$ & $(-1.84)$ & $(-2.95)$ \\
\hline \multirow[t]{2}{*}{ Duality } & -0.003 & 0.019 & 0.000 & 0.009 & -0.028 \\
\hline & $(-0.12)$ & $(0.96)$ & $(0.01)$ & $(0.48)$ & $(-1.22)$ \\
\hline \multirow[t]{2}{*}{ Duality-destroying event } & 0.017 & 0.011 & -0.005 & -0.020 & $0.051^{*}$ \\
\hline & $(0.76)$ & $(0.43)$ & $(-0.19)$ & $(-0.68)$ & $(1.97)$ \\
\hline \multirow{2}{*}{$\begin{array}{l}\text { Departing founder CEO remains on board } \\
\text { postevent }\end{array}$} & & & -0.033 & 0.003 & 0.017 \\
\hline & & & $(-0.85)$ & $(0.14)$ & $(0.73)$ \\
\hline \multicolumn{6}{|l|}{ Control variables } \\
\hline \multirow[t]{2}{*}{ Ln(total assets) } & -0.000 & 0.002 & -0.000 & -0.006 & -0.000 \\
\hline & $(-0.02)$ & $(0.36)$ & $(-0.06)$ & $(-1.26)$ & $(-0.08)$ \\
\hline \multirow[t]{2}{*}{ Return on assets } & $0.148^{* *}$ & -0.027 & $0.236^{* *}$ & $0.192^{* * *}$ & $0.149^{*}$ \\
\hline & $(2.16)$ & $(-0.31)$ & $(2.27)$ & $(3.08)$ & $(1.90)$ \\
\hline \multirow[t]{2}{*}{ Total debt/total assets } & -0.026 & $-0.124^{* *}$ & -0.028 & 0.042 & $-0.108^{*}$ \\
\hline & $(-0.60)$ & $(-2.51)$ & $(-0.46)$ & $(0.92)$ & $(-1.92)$ \\
\hline \multirow[t]{2}{*}{ Book-to-market } & -0.005 & -0.012 & -0.008 & -0.001 & -0.004 \\
\hline & $(-0.65)$ & $(-1.09)$ & $(-0.53)$ & $(-0.10)$ & $(-0.30)$ \\
\hline \multirow[t]{2}{*}{ Loss } & $-0.056^{* *}$ & $-0.063^{* * *}$ & $-0.043^{*}$ & -0.033 & $-0.046^{* *}$ \\
\hline & $(-2.57)$ & $(-3.37)$ & $(-1.68)$ & $(-1.18)$ & $(-2.09)$ \\
\hline
\end{tabular}


TABLE 4 (Continued)

\begin{tabular}{lllllll} 
& Year -2 & Year -1 & Year 0 & Year 1 & Year 2 \\
\hline Big Four & -0.014 & -0.011 & $-0.028^{*}$ & 0.001 & -0.011 \\
& $(-0.96)$ & $(-0.78)$ & $(-1.85)$ & $(0.04)$ & $(-0.75)$ \\
France & -0.027 & -0.003 & 0.038 & -0.006 & 0.028 \\
& $(-1.30)$ & $(-0.12)$ & $(1.64)$ & $(-0.26)$ & $(1.07)$ \\
Germany & 0.000 & $0.046^{* *}$ & 0.029 & 0.003 & 0.010 \\
& $(0.01)$ & $(1.99)$ & $(1.38)$ & $(0.14)$ & $(0.52)$ \\
Year and industry dummies & Yes & Yes & Yes & Yes & Yes \\
Constant & 0.028 & -0.065 & -0.043 & 0.056 & 0.130 \\
& $(0.32)$ & $(-0.76)$ & $(-0.51)$ & $(0.64)$ & $(1.26)$ \\
\hline No. of observations & 133 & 149 & 153 & 153 & 147 \\
\hline Adj. $R^{2}$ & 0.200 & 0.157 & 0.265 & 0.111 & 0.208 \\
\hline
\end{tabular}

\section{Private benefits of control}

We find strong evidence (at the $1 \%$ level of significance) that the departing CEO in dualitydestroying events who remains on the board postevent inflates earnings upwards preevent compared to the departing CEO who leaves the board postevent. Again, this is only the case when comparing founder CEO reappointments with nonfamily CEOs as the coefficient on the duality-destroying event dummy is insignificant in Table $4 .^{24}$ This suggests that a departing family CEO, who also acts as the chair of the board of directors preevent, inflates earnings upwards to ensure a seat on the board of directors and maintain oversight over the nonfamily successor CEO postevent. This result is in line with our argument that the costs and benefits of the controlling family to engage in earning management change over time. In this particular case, the family CEO maintains significant control over the firm preevent via the family voting rights as well as by holding the chair and CEO positions. By appointing a nonfamily CEO for the first time, the departing family CEO has greater incentives to remain on the board and consequently maintain oversight over the firm, thereby protecting the wealth of the family.

\section{Country effects}

We find that the regression coefficients on the dummy variables for France and Germany are insignificant in four out of the five regressions reported in Table 3. The coefficients are significant at the $10 \%$ level in the regression based on year 0 . In particular, we find that actual accruals deviate from predicted accruals in the event year by an additional 3.2 and 3.5 percentage points of total assets for French and German firms, respectively, when compared to UK firms. Similar but stronger results are found in Table 4 for German firms only when comparing founder CEO reappointments with new family CEOs in year -1 . Overall, this evidence is in line

\footnotetext{
${ }^{24}$ By construction, there are no duality-destroying events or instances when the departing founder CEO remains on the board postevent when comparing founder CEO reappointments with other reappointments in Table 5.
} 
TABLE 5 Comparing earnings management around founder CEO reappointments and other reappointments

This table reports the ordinary least square regressions for accrual-based earnings management on the other reappointments dummy, the measures of private benefits of control as well as a set of control variables measured in year $t$. It focuses on 192 events in family firms of which 134 are founder CEO reappointments and 58 are other reappointments. The regressions compare other reappointments with founder CEO reappointments. Other reappointment dummy takes a value of one if the nonfounder CEO is reappointed, and zero otherwise. The three measures of private benefits of control are: the family wedge dummy, board independence and duality. There are no duality-destroying events as well as events with a departing founder CEO on board postevent in this sample as the incumbent CEO is always reappointed. The control variables, except for the loss dummy, Big Four, country and year dummies, are winsorized at the 2nd and the 98th percentiles. Year 0 is the event year, that is, the first full fiscal year during which the incumbent CEO is no longer in office. In case of reappointments, year 0 is the fiscal year following the fiscal year of the reappointment date. The $t$ values presented in parentheses are heteroscedasticity consistent and the standard errors are clustered by firm. ${ }^{*}, * *$ and ${ }^{* * *}$ stand for statistical significance at the $10 \%, 5 \%$ and $1 \%$ level, respectively.

\begin{tabular}{|c|c|c|c|c|c|}
\hline & Year -2 & Year -1 & Year 0 & Year 1 & Year 2 \\
\hline \multirow[t]{2}{*}{ Other reappointments } & -0.013 & -0.021 & -0.020 & -0.024 & -0.026 \\
\hline & $(-1.04)$ & $(-1.37)$ & $(-1.18)$ & $(-1.58)$ & $(-1.42)$ \\
\hline \multicolumn{6}{|l|}{ Private benefits of control } \\
\hline \multirow{2}{*}{ Family wedge dummy } & 0.000 & 0.006 & -0.004 & -0.001 & 0.002 \\
\hline & $(0.03)$ & $(0.30)$ & $(-0.26)$ & $(-0.07)$ & $(0.16)$ \\
\hline \multirow[t]{2}{*}{ Board independence } & 0.002 & 0.003 & -0.021 & -0.046 & $-0.066^{*}$ \\
\hline & $(0.07)$ & $(0.10)$ & $(-0.55)$ & $(-1.28)$ & $(-1.76)$ \\
\hline \multirow[t]{2}{*}{ Duality } & 0.002 & -0.004 & -0.009 & 0.018 & -0.010 \\
\hline & $(0.14)$ & $(-0.24)$ & $(-0.56)$ & $(1.12)$ & $(-0.51)$ \\
\hline \multicolumn{6}{|l|}{ Control variables } \\
\hline \multirow[t]{2}{*}{$\operatorname{Ln}$ (total assets) } & 0.003 & 0.003 & 0.002 & -0.001 & 0.004 \\
\hline & $(0.52)$ & $(0.67)$ & $(0.37)$ & $(-0.15)$ & $(0.83)$ \\
\hline \multirow[t]{2}{*}{ Return on assets } & $0.134^{* *}$ & -0.042 & $0.201^{*}$ & $0.183^{* * *}$ & 0.059 \\
\hline & $(2.41)$ & $(-0.60)$ & $(1.87)$ & $(3.02)$ & $(0.64)$ \\
\hline \multirow[t]{2}{*}{ Total debt/total assets } & -0.037 & -0.079 & -0.014 & 0.072 & $-0.113^{*}$ \\
\hline & $(-0.85)$ & $(-1.58)$ & $(-0.24)$ & $(1.63)$ & $(-1.98)$ \\
\hline \multirow[t]{2}{*}{ Book-to-market } & -0.006 & $-0.020^{*}$ & -0.011 & -0.012 & -0.006 \\
\hline & $(-0.88)$ & $(-1.91)$ & $(-0.74)$ & $(-1.23)$ & $(-0.45)$ \\
\hline \multirow[t]{2}{*}{ Loss } & $-0.076^{* * *}$ & $-0.063^{* * *}$ & $-0.055^{*}$ & -0.031 & $-0.054^{* * *}$ \\
\hline & $(-3.82)$ & $(-3.36)$ & $(-1.95)$ & $(-1.23)$ & $(-2.79)$ \\
\hline \multirow[t]{2}{*}{ Big Four } & -0.017 & -0.021 & -0.022 & -0.010 & -0.015 \\
\hline & $(-1.39)$ & $(-1.58)$ & $(-1.59)$ & $(-0.87)$ & $(-1.15)$ \\
\hline \multirow[t]{2}{*}{ France } & -0.010 & v0.012 & 0.027 & -0.004 & 0.010 \\
\hline & $(-0.56)$ & $(-0.69)$ & $(1.33)$ & (v0.19) & $(0.43)$ \\
\hline
\end{tabular}


TABLE 5 (Continued)

\begin{tabular}{|llllll|}
\hline & Year $\mathbf{- 2}$ & Year $\mathbf{- 1}$ & Year 0 & Year 1 & Year 2 \\
\hline Germany & -0.001 & 0.009 & 0.013 & 0.002 & 0.001 \\
& $(-0.04)$ & $(0.51)$ & $(0.66)$ & $(0.13)$ & $(0.06)$ \\
\multicolumn{1}{c}{ Year and industry dummies } & Yes & Yes & Yes & Yes & Yes \\
\hline Constant & $0.118^{* *}$ & $0.088^{*}$ & 0.056 & -0.067 & -0.021 \\
& $(2.21)$ & $(1.73)$ & $(0.95)$ & $(-1.44)$ & $(-0.41)$ \\
\hline No. of observations & 148 & 163 & 165 & 167 & 165 \\
\hline Adj. $R^{2}$ & 0.303 & 0.153 & 0.233 & 0.170 & 0.183 \\
\hline
\end{tabular}

with Leuz et al. (2003) who find that earnings management is more prevalent in countries with weak investor protection. However, our results are weak from a statistical point of view and not consistent across the 2 years before and the 2 years after the event. This is not surprising given that the three countries in our sample are well-developed economies, with large stock markets and a high proportion of firms cross-listed on foreign stock exchanges associated with high investor protection.

\section{Endogeneity concerns}

This paper studies earnings management around CEO reappointments and successions. This focus implicitly assumes that the actual CEO changes happen irrespective of whether there is earnings management or not, and irrespective of the type and/or direction of earnings management. However, it might be the case that the CEO changes are not exogenous. Importantly, Hazarika et al. (2012) suggest that forced CEO changes are more likely following earnings management and that it is the amount rather than the direction of the earnings management that increases the likelihood of a forced CEO change. They find that this pattern holds even after adjusting for financial performance. They interpret this as evidence that boards of directors punish CEOs engaging in aggressive earnings management given its costs (i.e., reduced earnings quality). Hence, it is important to adjust for the potential endogeneity of earnings management. To address this issue, we run logit regressions regressing the forced succession dummy variable (as defined in Section 5.3) as the dependent variable on the absolute value of accrual-based earnings management in year -2 or/and year -1 , as well as the control variables, country, industry and year dummies as the independent variables. The regression results tabulated in Table 6 show that all our measures of absolute earnings management in year -2 , as well as year -1 , are insignificant, suggesting that our results are not driven by reverse causality.

Also, the motives of the founder CEO for transferring the management to another family member or to a nonfamily CEO may be affected by the family's control over the firm as well as the stage at which the firm is in its life cycle. More specifically, it is possible that the founder CEO is more likely to be reappointed when the firm is in its growing stage whereas the position of the CEO is more likely to be transferred to another candidate when the firm is already mature. As discussed in Section 5, our results are robust when we control for firm age in all the regressions in Table 3. However, to further mitigate endogeneity concerns, we utilize propensity score matching (PSM) to match founder CEO reappointments with other events while taking 
TABLE 6 Logit regressions testing whether the absolute values of past abnormal accruals explain the probability of a forced succession

This table reports as well as tests the validity of the Hazarika et al. (2012) hypothesis that forced CEO changes are more likely following earnings management and that it is the amount rather than the direction of earnings management that increases the likelihood of a forced CEO change. The first three columns report the logit regressions regressing the forced succession dummy variable on the absolute value of abnormal accruals in year -2 or/and year -1 , and country, industry and year dummies. The regressions in columns (4), (5) and (6) also include our control variables. The forced succession dummy variable equals one if the CEO change is a forced succession, and zero otherwise. Forced successions are CEO changes for which there is news stating that the CEO was 'replaced', or the CEO left following 'policy disagreements', left due to 'differences in opinion', or some other similar reason. The absolute value of abnormal accruals as well as the control variables, except for the loss dummy, Big Four, country and year dummies are winsorized at the 2nd and the 98th percentiles. Year 0 is the event year, that is, the first full fiscal year during which the incumbent CEO is no longer in office. In case of reappointments, year 0 is the fiscal year following the fiscal year of the reappointment date. The $t$ values presented in parentheses are heteroscedasticity consistent and the standard errors are clustered by firm. * ** and *** stand for statistical significance at the $10 \%, 5 \%$ and $1 \%$ level, respectively.

\begin{tabular}{|c|c|c|c|c|c|c|}
\hline & (1) & (2) & (3) & (4) & (5) & (6) \\
\hline $\begin{array}{l}\text { Absolute value of abnormal accruals in } \\
\quad \text { year }-2\end{array}$ & $\begin{array}{l}-5.624 \\
(-1.09)\end{array}$ & & $\begin{array}{l}-10.326 \\
(-1.55)\end{array}$ & $\begin{array}{l}-8.263 \\
(-1.10)\end{array}$ & & $\begin{array}{l}-10.724 \\
(-1.36)\end{array}$ \\
\hline $\begin{array}{l}\text { Absolute value of abnormal accruals in } \\
\text { year }-1\end{array}$ & & $\begin{array}{l}1.898 \\
(0.50)\end{array}$ & $\begin{array}{l}7.923 \\
(1.46)\end{array}$ & & $\begin{array}{l}0.272 \\
(0.05)\end{array}$ & $\begin{array}{l}4.087 \\
(0.80)\end{array}$ \\
\hline Control variables & & & & & & \\
\hline $\operatorname{Ln}$ (total assets) & & & & $\begin{array}{l}0.209 \\
(0.81)\end{array}$ & $\begin{array}{l}0.334 \\
(1.39)\end{array}$ & $\begin{array}{l}0.200 \\
(0.79)\end{array}$ \\
\hline Return on assets & & & & $\begin{array}{l}-1.073 \\
(-0.61)\end{array}$ & $\begin{array}{l}-1.951 \\
(-1.01)\end{array}$ & $\begin{array}{l}-0.927 \\
(-0.52)\end{array}$ \\
\hline Total debt/total assets & & & & $\begin{array}{l}0.713 \\
(0.35)\end{array}$ & $\begin{array}{l}0.829 \\
(0.47)\end{array}$ & $\begin{array}{l}1.051 \\
(0.52)\end{array}$ \\
\hline Book-to-market & & & & $\begin{array}{l}-0.269 \\
(-0.54)\end{array}$ & $\begin{array}{l}-0.123 \\
(-0.30)\end{array}$ & $\begin{array}{l}-0.292 \\
(-0.61)\end{array}$ \\
\hline Loss & & & & $\begin{array}{l}1.301 \\
(1.24)\end{array}$ & $\begin{array}{l}0.819 \\
(0.73)\end{array}$ & $\begin{array}{l}1.252 \\
(1.21)\end{array}$ \\
\hline Big Four & & & & $\begin{array}{l}0.283 \\
(0.37)\end{array}$ & $\begin{array}{l}0.178 \\
(0.23)\end{array}$ & $\begin{array}{l}0.279 \\
(0.37)\end{array}$ \\
\hline France & $\begin{array}{l}-1.527^{* *} \\
(-2.10)\end{array}$ & $\begin{array}{l}-1.485^{* *} \\
(-2.15)\end{array}$ & $\begin{array}{l}-1.415^{*} \\
(-1.93)\end{array}$ & $\begin{array}{l}-2.435^{* *} \\
(-2.16)\end{array}$ & $\begin{array}{l}-2.666^{* *} \\
(-2.53)\end{array}$ & $\begin{array}{l}-2.397^{* * *} \\
(-2.10)\end{array}$ \\
\hline Germany & $\begin{array}{l}-1.052 \\
(-1.51)\end{array}$ & $\begin{array}{l}-1.250^{*} \\
(-1.66)\end{array}$ & $\begin{array}{l}-1.369^{*} \\
(-1.79)\end{array}$ & $\begin{array}{l}-1.521^{*} \\
(-1.95)\end{array}$ & $\begin{array}{l}-1.919 * * \\
(-2.46)\end{array}$ & $\begin{array}{l}-1.686^{* *} \\
(-2.19)\end{array}$ \\
\hline Year and industry dummies & Yes & Yes & Yes & Yes & Yes & Yes \\
\hline
\end{tabular}


TABLE 6 (Continued)

\begin{tabular}{|lllllll|}
\hline Constant & $\mathbf{( 1 )}$ & $\mathbf{( 2 )}$ & $\mathbf{( 3 )}$ & $\mathbf{( 4 )}$ & $\mathbf{( 5 )}$ & $\mathbf{( 6 )}$ \\
& $1.860^{*}$ & 1.315 & $2.047^{*}$ & -0.053 & -1.837 & 0.084 \\
\hline No. of observations & $(1.67)$ & $(1.28)$ & $(1.80)$ & $(-0.02)$ & $(-0.66)$ & $(0.03)$ \\
\hline Pseudo $R^{2}$ & 186 & 204 & 185 & 182 & 196 & 181 \\
\hline Wald $\chi^{2}$ & 0.258 & 0.253 & 0.272 & 0.353 & 0.343 & 0.355 \\
\hline
\end{tabular}

family control into account (Rosenbaum \& Rubin, 1983). To achieve this, we first run a logit regression using the founder $\mathrm{CEO}$ reappointment dummy as the dependent variable, while including family control and our control variables used in the regressions reported in Table 3 on the right-hand side. The founder CEO reappointment dummy takes a value of one if the incumbent founder CEO is reappointed, and zero otherwise. All independent variables are measured in year -1 . Second, a propensity score is then generated for all the events. Our aim is to match events involving a founder CEO reappointment with other events in the same industry (using ICB from Datastream). Hence, next, we generate an amended propensity score to account for the industry-specific characteristics. ${ }^{25}$ Using the latter score we then match the events based on the nearest neighbour approach with a maximum caliper distance of 0.1 to minimize the systematic differences between the matches. Our measure of earnings management in year -1 is used as the outcome in the matching process. This approach allows us to match the events in terms of their propensity score while preserving the industrial closeness of the firms with and without a reappointed founder CEO. We manage to match 116 of the 134 events with a reappointed founder CEO with other events. ${ }^{26}$

The prematching logit and the postmatching logits are reported in the first two columns of Table 7. The prematching logit has a pseudo- $R^{2}$ with a value of 0.079 and some of the independent variables have statistically significant coefficients. However, as expected, the logits reestimated for the matched sample (see the second column of Table 7) have little explanatory power as their pseudo- $R^{2}$ is close to zero and the coefficients on all the independent variables are insignificant. We also use mean and median comparisons to test for differences between the events involving reappointed founder CEOs and other events for each of the explanatory variables included in the propensity score logit regression. Untabulated results suggest that there are no statistically significant differences between the two samples. Hence, we are confident that our matching is of good quality.

Next, we rerun the OLS regressions reported in Tables 3-5 on the matched sample of events in reappointed founder CEO and other events in family firms. The regression results reported in Panel A of Table 8 strongly corroborate our main result that reappointed founder CEOs engage in upward earnings management in the years preceding the event compared to nonfamily CEO appointments in family firms. The coefficients on the nonfamily CEO in Panel A of Table 8 are negative and significant at the $5 \%$ level in years -2 and -1 . The coefficients on the new family

\footnotetext{
${ }^{25}$ The propensity scores obtained from the previous step are transformed via the following formula: Amended Propensity Score = Industry Code $\times 10+$ Propensity Score. No matching by year is required as we use relative years in the analysis. ${ }^{26}$ To increase the number of matches, we allow the firms without a founder CEO reappointment to be used more than once as a match for the firms that reappoint their founder CEO.
} 
TA B LE 7 Pre- and postmatching logits matching reappointed founder CEO events (events in founder firms) with other events in family firms (events in nonfounder firms)

This table reports the results of the logit regressions underlying the propensity score matching for the prematching sample and the postmatching sample when using accrual-based earnings management in year -1 as an outcome in the matching process. The dependent variable in the logit regressions reported in the first two columns is the reappointed founder CEO dummy which equals one if the incumbent founder CEO is reappointed, and zero otherwise. The dependent variable in the logit regressions reported in the last two columns is the founder dummy which takes a value of one if the founder (the person that founded the firm) is the incumbent CEO and zero otherwise. The control variables, except for the loss dummy and Big Four are winsorized at the 2nd and the 98th percentiles. Year 0 is the event year, that is, the first full fiscal year during which the incumbent CEO is no longer in office. In case of reappointments, year 0 is the fiscal year following the fiscal year of the reappointment date. The $t$ values presented in parentheses are heteroscedasticity consistent and the standard errors are clustered by firm. ${ }^{*}, * *$ and ${ }^{* * *}$ stand for statistical significance at the $10 \%, 5 \%$ and $1 \%$ level, respectively.

\begin{tabular}{|c|c|c|c|c|}
\hline & \multicolumn{2}{|c|}{$\begin{array}{l}\text { Matching founder reappointments } \\
\text { and other events in family firms }\end{array}$} & \multicolumn{2}{|c|}{$\begin{array}{l}\text { Matching founder and } \\
\text { nonfounder events }\end{array}$} \\
\hline & $\begin{array}{l}\text { Prematching } \\
\text { logit }\end{array}$ & $\begin{array}{l}\text { Postmatching } \\
\text { logit }\end{array}$ & $\begin{array}{l}\text { Prematching } \\
\text { logit }\end{array}$ & $\begin{array}{l}\text { Postmatching } \\
\text { logit }\end{array}$ \\
\hline \multicolumn{5}{|l|}{ Private benefits of control } \\
\hline \multirow[t]{2}{*}{ Family control } & -1.417 & -0.792 & -1.754 & -1.356 \\
\hline & $(-1.47)$ & $(-0.50)$ & $(-1.61)$ & $(-1.05)$ \\
\hline \multicolumn{5}{|l|}{ Control variables } \\
\hline \multirow[t]{2}{*}{ Ln (total assets) } & $-0.334^{* * *}$ & 0.024 & $-0.397^{* * *}$ & -0.099 \\
\hline & $(-3.01)$ & $(0.14)$ & $(-3.41)$ & $(-0.65)$ \\
\hline \multirow[t]{2}{*}{ Return on assets } & 0.529 & -0.308 & -1.110 & -0.045 \\
\hline & $(0.53)$ & $(-0.23)$ & $(-0.76)$ & $(-0.03)$ \\
\hline \multirow[t]{2}{*}{ Total debt/total assets } & -0.536 & -1.312 & -0.704 & 0.614 \\
\hline & $(-0.57)$ & $(-0.92)$ & $(-0.72)$ & $(0.45)$ \\
\hline \multirow[t]{2}{*}{ Book-to-market } & $-0.536^{* *}$ & -0.235 & $-0.777^{* * *}$ & -0.444 \\
\hline & $(-2.38)$ & $(-0.60)$ & $(-3.22)$ & $(-1.36)$ \\
\hline \multirow[t]{2}{*}{ Loss } & 0.115 & 0.068 & $0.969^{* *}$ & 0.441 \\
\hline & $(0.29)$ & $(0.11)$ & $(2.05)$ & $(0.77)$ \\
\hline \multirow[t]{2}{*}{ Big Four } & 0.020 & -0.579 & -0.036 & 0.126 \\
\hline & $(0.06)$ & $(-1.36)$ & $(-0.11)$ & $(0.31)$ \\
\hline \multirow[t]{2}{*}{ Constant } & $4.903^{* * *}$ & 2.222 & $6.818^{* * *}$ & $3.195^{*}$ \\
\hline & $(3.63)$ & $(1.16)$ & $(4.66)$ & $(1.86)$ \\
\hline No. of observations & 286 & 147 & 286 & 174 \\
\hline Pseudo $R^{2}$ & 0.079 & 0.024 & 0.143 & 0.022 \\
\hline$\chi^{2}$ & 21.35 & 3.12 & 33.83 & 3.91 \\
\hline$p$ Value for $\chi^{2}$ & 0.000 & 0.874 & 0.000 & 0.790 \\
\hline Number of matched firms & - & 116 & - & 131 \\
\hline
\end{tabular}


TABLE 8 Propensity score matching of founder reappointments with other events in family firms

This table reports the replicated ordinary least square (OLS) regressions reported in Tables 3-5 using propensity score matching founder reappointments with other events in family firms. The regressions results reported in Panels A to C compare nonfamily CEOs, new family CEOs and other reappointments with founder CEO reappointments respectively. The nonfamily CEO appointment dummy takes a value of one if a nonfamily CEO is appointed, and zero otherwise. The new family CEO is set to one if a new family CEO is appointed, and zero otherwise. Other reappointment dummy takes a value of one if the nonfounder CEO is reappointed, and zero otherwise. All three panels report the OLS regressions for accrual-based earnings management on the respective event type dummies, the measures of private benefits of control as well as a set of control variables measured in year $t$. Year 0 is the event year, that is, the first full fiscal year during which the incumbent CEO is no longer in office. In case of reappointments, year 0 is the fiscal year following the fiscal year of the reappointment date. The $t$ values presented in parentheses are heteroscedasticity consistent and the standard errors are clustered by firm. $*, * *$ and ${ }^{* * *}$ stand for statistical significance at the $10 \%, 5 \%$ and $1 \%$ level, respectively.

\begin{tabular}{|c|c|c|c|c|c|}
\hline & Year -2 & Year -1 & Year 0 & Year 1 & Year 2 \\
\hline \multicolumn{6}{|c|}{ Panel A: Nonfamily CEO compared to founder CEO reappointment } \\
\hline \multirow[t]{2}{*}{ Nonfamily CEO } & $-0.053^{* *}$ & $-0.055^{* *}$ & -0.011 & 0.024 & -0.015 \\
\hline & $(2.31)$ & $(2.44)$ & $(0.39)$ & $(-1.22)$ & $(0.62)$ \\
\hline Private benefits of control & Yes & Yes & Yes & Yes & Yes \\
\hline Control variables & Yes & Yes & Yes & Yes & Yes \\
\hline \multirow[t]{2}{*}{ France } & -0.007 & 0.004 & $0.043^{*}$ & -0.012 & 0.015 \\
\hline & $(-0.28)$ & $(0.16)$ & $(1.67)$ & $(-0.53)$ & $(0.55)$ \\
\hline \multirow[t]{2}{*}{ Germany } & -0.000 & 0.028 & $0.043^{*}$ & 0.006 & -0.003 \\
\hline & $(-0.00)$ & $(1.20)$ & $(1.78)$ & $(0.31)$ & $(-0.16)$ \\
\hline Year and industry dummies & Yes & Yes & Yes & Yes & Yes \\
\hline \multirow[t]{2}{*}{ Constant } & -0.071 & 0.010 & 0.038 & 0.032 & 0.031 \\
\hline & $(-0.84)$ & $(0.15)$ & $(0.50)$ & $(0.46)$ & $(0.39)$ \\
\hline No. of observations & 122 & 141 & 141 & 141 & 143 \\
\hline Adj. $R^{2}$ & 0.354 & 0.249 & 0.230 & 0.209 & 0.224 \\
\hline \multicolumn{6}{|c|}{ Panel B: New family CEO compared to founder CEO reappointment } \\
\hline \multirow[t]{2}{*}{ New family CEO } & 0.008 & 0.005 & 0.011 & 0.011 & -0.044 \\
\hline & $(-0.20)$ & $(-0.13)$ & $(-0.35)$ & $(-0.33)$ & $(1.20)$ \\
\hline Private benefits of control & Yes & Yes & Yes & Yes & Yes \\
\hline Control variables & Yes & Yes & Yes & Yes & Yes \\
\hline \multirow[t]{2}{*}{ France } & -0.018 & 0.006 & $0.052^{* *}$ & -0.008 & 0.028 \\
\hline & $(-0.75)$ & $(0.25)$ & $(2.06)$ & $(-0.33)$ & $(0.96)$ \\
\hline \multirow[t]{2}{*}{ Germany } & -0.001 & $0.052^{*}$ & 0.025 & 0.004 & 0.007 \\
\hline & $(-0.02)$ & $(1.94)$ & $(1.09)$ & $(0.17)$ & $(0.34)$ \\
\hline Year and industry dummies & Yes & Yes & Yes & Yes & Yes \\
\hline
\end{tabular}


TABLE 8 (Continued)

\begin{tabular}{llllll} 
& Year -2 & Year $-\mathbf{1}$ & Year 0 & Year 1 & Year 2 \\
Constant & 0.065 & -0.101 & -0.205 & -0.139 & 0.027 \\
& $(0.66)$ & $(-1.31)$ & $(-1.64)$ & $(-1.54)$ & $(0.34)$ \\
No. of observations & 112 & 128 & 129 & 128 & 122 \\
Adj. $R^{2}$ & 0.185 & 0.174 & 0.295 & 0.155 & 0.206 \\
Panel C: Other reappointments compared to founder CEO reappointments & & \\
Other reappointments & -0.016 & -0.025 & -0.023 & -0.026 & -0.031 \\
& $(1.01)$ & $(1.31)$ & $(1.01)$ & $(1.20)$ & $(1.29)$ \\
Private benefits of control & Yes & Yes & Yes & Yes & Yes \\
Control variables & Yes & Yes & Yes & Yes & Yes \\
France & -0.016 & -0.017 & 0.026 & -0.014 & 0.008 \\
& $(-0.77)$ & $(-0.79)$ & $(1.14)$ & $(-0.54)$ & $(0.29)$ \\
Germany & -0.011 & 0.020 & 0.013 & -0.005 & 0.001 \\
& $(-0.51)$ & $(0.90)$ & $(0.58)$ & $(-0.25)$ & $(0.07)$ \\
Year and industry dummies & Yes & Yes & Yes & Yes & Yes \\
Constant & 0.038 & 0.089 & 0.028 & -0.076 & 0.021 \\
No. of observations & $(0.50)$ & $(1.20)$ & $(0.33)$ & $(-1.01)$ & $(0.29)$ \\
Adj. $R^{2}$ & 121 & 135 & 136 & 136 & 136 \\
\hline & 0.278 & 0.141 & 0.237 & 0.163 & 0.184 \\
\hline
\end{tabular}

CEO and other reappointments are insignificant in all the regressions reported in Panels B and $\mathrm{C}$ of Table 8. Overall, we still find strong support for our hypothesis after matching events involving reappointed founder CEOs and other events in family firms.

The motives of the controlling family for retaining control of the firm are idiosyncratic, unobservable, and may be correlated with the decision to manage earnings. ${ }^{27}$ Furthermore, family firms might also face a different type of decision when reappointing the founder CEO compared to appointing the nonfounder CEO. Following a similar matching process as described above, only that now we use the founder CEO dummy as the dependent variable, we are able to match 131 of the 182 events with a founder CEO with events without a founder CEO. The founder CEO dummy takes a value of one if the founder is the incumbent CEO, and zero otherwise. The prematching logit and the postmatching logits are reported in the last two columns of Table 7 . We then rerun our main regression for the sample of founder CEOs matched with nonfounder events. The regression results reported in Panel A of Table 9 provide further, strong confirmation of our main result that reappointed founder CEOs engage in

\footnotetext{
${ }^{27} \mathrm{~A}$ similar endogeneity concern arises when comparing events in family and nonfamily firms. In particular, the decision to retain control through the CEO position is likely correlated with the decision to either maintain or reduce control in family firms. Yet, this is not the case for nonfamily firms as the decision to reappoint or replace the CEO is less likely to go hand-in-hand with control changes. Untabulated results show that we find support for our hypothesis that reappointed founder CEOs in family firms inflated earnings upwards preevent when using propensity score matching to pair family and nonfamily firms.
} 
TA BLE 9 Propensity score matching of events in firms with founder CEOs with events in firms with nonfounder CEOs

This table reports the replicated ordinary least square (OLS) regressions reported in Tables 3-5 using propensity score matching of events in founder firms with those in nonfounder firms. The regressions results reported in Panels A-C compare appointments of nonfamily CEOs, appointments of new family CEOs and other reappointments with founder CEO reappointments, respectively. The nonfamily CEO appointment dummy takes a value of one if a nonfamily CEO is appointed, and zero otherwise. The new family CEO is set to one if a new family CEO is appointed, and zero otherwise. The other reappointment dummy takes a value of one if the nonfounder CEO is reappointed, and zero otherwise. All three panels report the OLS regressions for accrual-based earnings management on the respective event type dummies, the measures of private benefits of control as well as a set of control variables measured in year $t$. Year 0 is the event year, that is, the first full fiscal year during which the incumbent CEO is no longer in office. In case of reappointments, year 0 is the fiscal year following the fiscal year of the reappointment date. The $t$ values presented in parentheses are heteroscedasticity consistent and the standard errors are clustered by firm. *, ** and ${ }^{* * *}$ stand for statistical significance at the $10 \%, 5 \%$ and $1 \%$ level, respectively.

\begin{tabular}{|c|c|c|c|c|c|}
\hline & Year -2 & Year -1 & Year 0 & Year 1 & Year 2 \\
\hline \multicolumn{6}{|c|}{ Panel A: Nonfamily CEO compared to founder CEO reappointment } \\
\hline \multirow[t]{2}{*}{ Nonfamily CEO } & $-0.053^{* *}$ & -0.031 & -0.030 & 0.032 & -0.017 \\
\hline & $(-2.32)$ & $(-1.54)$ & $(-1.24)$ & $(1.53)$ & $(-0.82)$ \\
\hline Private benefits of control & Yes & Yes & Yes & Yes & Yes \\
\hline Control variables & Yes & Yes & Yes & Yes & Yes \\
\hline \multirow[t]{2}{*}{ France } & 0.007 & 0.015 & $0.043^{*}$ & -0.011 & 0.019 \\
\hline & $(0.30)$ & $(0.64)$ & $(1.76)$ & $(-0.45)$ & $(0.78)$ \\
\hline \multirow[t]{2}{*}{ Germany } & -0.011 & 0.017 & 0.018 & -0.000 & -0.001 \\
\hline & $(-0.39)$ & $(0.62)$ & $(0.80)$ & $(-0.00)$ & $(-0.04)$ \\
\hline Year and industry dummies & Yes & Yes & Yes & Yes & Yes \\
\hline \multirow[t]{2}{*}{ Constant } & 0.058 & 0.082 & 0.041 & -0.016 & 0.066 \\
\hline & $(0.67)$ & $(1.09)$ & $(0.47)$ & $(-0.20)$ & $(0.82)$ \\
\hline No. of observations & 119 & 136 & 136 & 136 & 138 \\
\hline Adj. $R^{2}$ & 0.207 & 0.164 & 0.247 & 0.138 & 0.183 \\
\hline \multicolumn{6}{|c|}{ Panel B: New family CEO compared to founder CEO reappointment } \\
\hline \multirow[t]{2}{*}{ New family CEO } & 0.018 & 0.018 & 0.000 & 0.001 & -0.036 \\
\hline & $(0.78)$ & $(0.69)$ & $(0.01)$ & $(0.04)$ & $(-1.37)$ \\
\hline Private benefits of control & Yes & Yes & Yes & Yes & Yes \\
\hline Control variables & Yes & Yes & Yes & Yes & Yes \\
\hline \multirow[t]{2}{*}{ France } & -0.027 & -0.009 & 0.036 & -0.008 & 0.028 \\
\hline & $(-1.23)$ & $(-0.35)$ & $(1.41)$ & $(-0.33)$ & $(1.02)$ \\
\hline \multirow[t]{2}{*}{ Germany } & -0.004 & $0.048^{*}$ & 0.030 & 0.012 & 0.014 \\
\hline & $(-0.17)$ & $(1.97)$ & (1.34) & $(0.51)$ & $(0.70)$ \\
\hline Year and industry dummies & Yes & Yes & Yes & Yes & Yes \\
\hline
\end{tabular}


TABLE 9 (Continued)

\begin{tabular}{llllll} 
& Year -2 & Year $\mathbf{- 1}$ & Year 0 & Year 1 & Year 2 \\
Constant & 0.096 & -0.101 & -0.109 & -0.021 & 0.070 \\
& $(1.30)$ & $(-1.45)$ & $(-1.04)$ & $(-0.21)$ & $(0.91)$ \\
No. of observations & 121 & 138 & 139 & 139 & 132 \\
Adj. $R^{2}$ & 0.218 & 0.170 & 0.267 & 0.130 & 0.220 \\
Panel C: Other reappointments compared to founder CEO reappointments & & \\
Other reappointments & -0.017 & $-0.028^{*}$ & -0.019 & -0.022 & -0.030 \\
& $(-1.22)$ & $(-1.75)$ & $(-0.92)$ & $(-1.25)$ & $(-1.51)$ \\
Private benefits of control & Yes & Yes & Yes & Yes & Yes \\
Control variables & Yes & Yes & Yes & Yes & Yes \\
France & -0.010 & -0.007 & 0.029 & -0.009 & 0.015 \\
& $(-0.50)$ & $(-0.33)$ & $(1.23)$ & $(-0.37)$ & $(0.53)$ \\
Germany & -0.007 & 0.019 & 0.018 & 0.005 & -0.001 \\
& $(-0.33)$ & $(0.96)$ & $(0.84)$ & $(0.27)$ & $(-0.03)$ \\
Year and industry dummies & Yes & Yes & Yes & Yes & Yes \\
Constant & $0.274^{* * *}$ & $0.131^{* *}$ & 0.052 & -0.081 & 0.050 \\
No. of observations & $(3.64)$ & $(2.03)$ & $(0.67)$ & $(-1.17)$ & $(0.63)$ \\
Adj. $R^{2}$ & 129 & 144 & 145 & 145 & 144 \\
\hline & 0.302 & 0.169 & 0.229 & 0.163 & 0.184 \\
\hline
\end{tabular}

upward accrual-based earnings management in the year preceding the event. The coefficients on the new family $\mathrm{CEO}$ and other reappointments are insignificant in all the regressions reported in Panels B and C of Table 9 with one exception. We find weak evidence (at the 10\% level) that reappointed founder CEOs inflate earnings in year -1 compared to other reappointments. We also find some further support in the first two panels of Table 9 for the finding that French and German firms inflate earnings to a greater extent than UK firms.

Overall, we find strong support for our findings when using PSM to match founder CEO reappointments with other events as well as when matching founder and nonfounder events.

\section{5 | ROBUSTNESS AND ADDITIONAL TESTS}

\section{1 | Introduction of the International Financial Reporting Standards (IFRS)}

France, Germany and the United Kingdom started implementing the IFRS in January 2005 (Nobes, 2011). Since the introduction of IFRS might have had an impact on the accounting figures used to calculate earnings management, we rerun all the regressions reported in Table 3 
for the years post-IFRS adoption, that is, the years 2006-2016. Our main results are upheld by these regressions.

\section{2 | Past firm performance}

In line with prior evidence (e.g., Achleitner et al., 2014), we include ROA measured in year $t$ in all the regressions to control for the impact of firm performance on earnings management. Nevertheless, it may be the case that it is not the level of performance but rather the change in performance that acts as a trigger for earnings manipulations. To address this concern, we replace the ROA in all the regressions with two dummy variables that account for the changes in performance 3 years before the event. In particular, ROA Increases Dummy takes a value of one if all the annual changes in ROA during the three years before the event are positive, and zero otherwise. In turn, ROA Decreases Dummy takes a value of one if all the annual changes in ROA during the 3 years before the event are negative, and zero otherwise. Untabulated results show that our main results are upheld.

\section{3 | Forced departures and deaths}

Twenty-six out of the 306 events are forced departures. These are departures for which there are news articles or news releases stating that the CEO was 'replaced', left following 'policy disagreements', left due to 'differences in opinion', or some other similar reason. For 21 out of the 26 forced departures, the departing CEO is replaced by a nonfamily CEO. For the remaining five forced departures, the family CEO is replaced by a new family CEO. Only 11 out of the 26 forced departures relate to a founder CEO. If we add a forced departures dummy variable to the regressions in Table 3, our main results are upheld. Finally, only six out of the 306 events relate to the death of the CEO and in all six events the family CEO is replaced by another family member. The results are qualitatively similar if we exclude these events from the sample.

\subsection{Incumbent and successor CEO characteristics}

We further verify the robustness of the results by including in the regressions in Table 3 the age and tenure of the incumbent CEO and the tenure of the successor CEO. ${ }^{28}$ These variables are insignificant in all the regressions. Importantly, our main results are upheld.

\section{5 | Number of times the founder CEO is reappointed}

It may be the case that founder CEOs who are reappointed more than once are more likely to engage in earnings management. In other words, such CEOs may be reappointed because of successfully manipulating earnings. To address this possibility, we generate a dummy variable,

\footnotetext{
${ }^{28}$ Of the 306 events in family firms, only six involve a female CEO. We also attempted to collect data on the incumbent CEO's gender and education. The data on education (e.g., university degree) proved to be difficult to obtain and we were able to obtain this information for only 66 events out of the 306 events.
} 
which equals one if the firm reappoints its founder CEO more than once, and zero otherwise. We then include this dummy variable in the regressions in Table 3. Twenty-six out of the 240 firms reappoint their founder CEO twice during the period of study, five firms reappoint their founder CEO three times and another two firms reappoint their founder CEO four times. Our main results are upheld after controlling for the number of times the founder CEO is reappointed.

\subsection{Market reaction and earnings management}

Our results suggest that firms that reappoint their founder CEO manage earnings upwards in year -1 . However, is the stock market fooled by this earnings manipulation? To answer this question, we compute cumulative abnormal returns (CARs) around the announcement of these events. The CARs are based on daily data for the market model, where Day 0 is the day of the event announcement. ${ }^{29}$ The parameters of the market model are estimated from Day -270 to Day -20. The STOXX Europe600 index is the proxy for the market portfolio.

Untabulated results suggest that there is no significant market reaction, as measured by CAR $[-1,1]$ and CAR $[-3,3]$, to the announcement of founder CEO reappointments as well as other events in family firms. The mean and median differences in abnormal returns across the two types of events (i.e., founder CEO reappointments and other events in family firms) are also insignificant. However, additional untabulated results show that there is a positive market reaction to the announcements of founder CEO reappointments, but only when the incumbent CEO engages in positive accrual-based earnings management in year -1 . This suggests that founder CEOs who are up for reappointment successfully manipulate earnings upwards, triggering a positive short-term market reaction to the announcement of their reappointment.

\section{7 | Does it matter if the CFO is part of the family?}

Prior evidence shows that chief financial officers (CFOs) have strong incentives to engage in earnings management. ${ }^{30}$ It is possible that such incentives are even stronger if the CFO is connected to the controlling family, which further enhances the ability of the founder CEO to manipulate earnings upwards before the reappointment. Hence, we explore whether it matters that the CFO in year -1 is a member of the controlling family or has ties with it. ${ }^{31}$ Untabulated results suggest that 108 out of the 306 events in family firms have a CFO in year -1 . Only 10 out of the 108 CFOs are part of the family, whereas 29 of them are not related to the family but have ties with it. The remaining CFOs are neither related to the family nor have any other ties to it. The vast majority of the events that take place in firms with a CFO related to the family or having ties with the family (34 out of 39 events) result in the reappointment of the founder CEO (20 events), the reappointment of the nonfounder CEO (nine events) and the appointment of a

\footnotetext{
${ }^{29}$ We use LexisNexis, the Forbes database and newspaper archives to identify the announcement date of each founder CEO reappointment. Wherever possible, the date is confirmed using more than one source.

${ }^{30}$ Jiang et al. (2010), for example, show that the magnitude of accruals and the likelihood of beating analyst forecasts are more sensitive to CFO equity incentives than to those of the CEO. Further, Baker et al. (2018) conclude that the power of the CEO relative to the CFO is an important factor in both the type and magnitude of earnings management.

${ }^{31}$ The CFO is considered to have ties with the family if he/she has been a director/executive in the same firm for more than 9 years or he/she serves on other boards with the family director(s).
} 
new family CEO (five events). A dummy variable, which takes the value of one if the CFO is part of the family or has ties to it, and zero otherwise, is included in all the regressions from Table 3. Untabulated results suggest that this dummy variable is insignificant in all the regressions. Importantly, our main results are upheld.

\section{8 | Further tests}

First, it is plausible that firms, which reappoint their founder CEO, are younger and also have greater risk. To control for these two firm characteristics, we rerun the regressions in Table 3 using firm age and the standard deviation of earnings per share based on years -4 to -1 . Untabulated regression results suggest that firm age and the standard deviation of earnings per share in years -4 to -1 are insignificant in all the regressions and our main results are upheld.

Second, given the importance of market returns in the CEO succession literature (e.g., Kaplan \& Minton, 2012), we replace the return on assets with the annual stock performance in the regressions in Table 3. Stock performance is measured as the annual change in the total return index of the stock divided by the total return index of the stock over the previous year. Untabulated results show that the latter is insignificant in all the regressions and our main results are upheld.

Third, we test the validity of our hypothesis by including the nonfamily CEO, new family CEO and other reappointments dummy variables in the same regression instead of running pairwise regressions. Untabulated regressions show that similar qualitative results are obtained using this alternative approach. More specifically, we still find that reappointed founder CEOs inflate earnings preevent.

Finally, to address the concern voiced by Gormley and Matsa (2014) that demeaning data multiple times might yield different results than the equivalent fixed effects, we rerun the regressions controlling for joint industry-year effects. Our main result is upheld.

\section{6 | CONCLUSION}

This paper studies accrual-based earnings management around the reappointment and the replacement of the incumbent family CEO in family firms from France, Germany and the United Kingdom. Our definition of a family firm is a firm with a family as its largest shareholder and holding at least $25 \%$ of the votes. Given the aim of the study, we only retain family firms whose incumbent CEO is a member of the controlling family and also only firms with at least one event, that is, one change in the CEO or at least one reappointment of the incumbent CEO.

We argue that founder CEOs hold a significant amount of socioemotional wealth in their firm and, in general, they will not engage in activities which could harm the firm. However, there is a breaking point at which the incentives of founder CEOs may change substantially. Founder CEO reappointments represent such events where the benefits of the founder CEO to engage in earnings management exceed the costs. More specifically, we hypothesize that founder CEOs who opt for reappointment have greater incentives, compared to later-generation family firms, to engage in earnings management around their reappointment. This is the case for the following reasons. First, given the socioemotional attachment founder CEOs have to 
their firms, they will aspire to maintain the CEO position and consequently they continue to be the main decision-maker in the firm, thereby protecting the wealth of the family. Second, reporting low earnings may increase the pressure from minority shareholders for the founder CEO to step down and appoint a successor, ideally a professional, nonfamily manager who may improve the performance of the firm. Finally, founder CEOs intent on being reappointed are likely to have in mind major projects enhancing the future success of the firm, which require their continuation as the CEO. In other words, their ongoing emotional and economic investment in the firm is such that having to step down as the CEO would result in a major loss to their investment.

In line with this argument, we find strong and consistent support for our hypothesis. In particular, we find that, in contrast to other family CEOs in family firms as well as CEOs in nonfamily firms, founder CEOs practice upward accrual-based earnings management in the year preceding their reappointment. Importantly, we do not find evidence that overall family firms are more likely to practice earnings management than nonfamily firms. On the contrary, similar to the existing literature, we find that family firms are less likely to engage in earnings management compared to nonfamily firms. Yet, this is not always the case as founder CEOs inflate earnings around their potential reappointment to secure a reappointment. Hence, in line with the argument put forward by Burgstahler and Chuk (2017), we find evidence that there is $a$ change over time in the costs and benefits of engaging in earnings management to meet specific benchmarks. Our results show that founder CEO reappointments in family firms trigger such change. To the best of our knowledge, this is the first study on earnings management by founder CEOs around their reappointment.

Our paper makes the following four contributions to the extant literature. First, it shows for the first time that the costs and benefits from earnings management change around founder CEO reappointments in family firms. We show that founder CEOs coming up for reappointment inflate earnings upwards to a greater extent than other family CEOs in the year preceding their reappointment. Second, for the first time, we show that it is important to differentiate between the types of incumbent family CEO when exploring earnings management as reappointed founder CEOs behave differently than other family CEOs. Third, we provide further support for the entrenchment effect of family firms and reappointed founder CEOs in particular. Finally, we find some evidence that French and German family firms engage in more earnings management around a family CEO succession or reappointment than UK firms. However, the results are weak from a statistical point of view and not consistent across the 2 years around the event. This is not surprising given that the three countries in our sample are well-developed economies, with large stock markets and a high proportion of firms cross-listed on foreign stock exchanges associated with higher investor protection.

Our paper generates important policy implications: Investors in family firms, as well as internal and external auditors and policymakers, should be aware of the temptation of founder CEOs to engage in upward earnings management preceding their reappointment.

\section{REFERENCES}

Achleitner, A.-K., Günther, N., Kaserer, C., \& Siciliano, G. (2014). Real earnings management and accrual-based earnings management in family firms. European Accounting Review, 23(3), 431-461. https://doi.org/10.1080/ 09638180.2014 .895620

Ali, A., Chen, T.-Y., \& Radhakrishnan, S. (2007). Corporate disclosures by family firms. Journal of Accounting and Economics, 44(1-2), 238-286. https://doi.org/10.1016/j.jacceco.2007.01.006 
Amiram, D., Bozanic, Z., Cox, J. D., Dupont, Q., Karpoff, J. M. \& Sloan, R. (2018). Financial reporting fraud and other forms of misconduct: A multidisciplinary review of the literature. Review of Accounting Studies, 23(2), 732-783. https://doi.org/10.1007/s11142-017-9435-x

Anderson, R., Martin, G., \& Reeb, D., (2017). Financial misconduct and family firms (Working Paper), Singapore.

Andres, C. (2008). Large shareholders and firm performance-An empirical examination of founding-family ownership. Journal of Corporate Finance, 14(4), 431-445. https://doi.org/10.1016/j.jcorpfin.2008.05.003

Ansari, I. F., Goergen, M. \& Mira, S. (2014). The determinants of the CEO successor choice in family firms. Journal of Corporate Finance, 28, 6-25. https://doi.org/10.1016/j.jcorpfin

Baker, T. A., Lopez, T. J., Reitenga, A. L. \& Ruch, G. W. (2018). The influence of CEO and CFO power on accruals and real earnings management. Review of Quantitative Finance and Accounting, 52(1), 325-345. https://doi.org/10.1007/s11156-018-0711-z

Ball, R., \& Shivakumar, L. (2005). Earnings quality in UK private firms: Comparative loss recognition timeliness. Journal of Accounting and Economics, 39(1), 83-128. https://doi.org/10.1016/j.jacceco.2004.04.001

Burgstahler, D., \& Chuk, E. (2017). What have we learned about earnings management? Integrating discontinuity evidence. Journal of Contemporary Accounting Research, 34(2), 726-749. https://doi.org/10. 1111/1911-3846.12301

Chen, X., Cheng, Q., \& Dai, Z. (2013). Family ownership and CEO turnovers. Contemporary Accounting Research, 30(3), 1166-1190. https://doi.org/10.1111/j.1911-3846.2012.01185.x

Choi, J. S., Kwak, Y. M., \& Choe, C. (2014). Earnings management surrounding CEO turnover: Evidence from Korea. Abacus, 50(1), 25-55. https://doi.org/10.1111/abac.12021

Cruz, C., Firfiray, S., \& Gomez-Mejia, L. R. (2011). Socioemotional wealth and human resource management (HRM) in family-controlled firms, Research in personnel and human resources management (Vol. 30, pp. 159-217). Emerald Group Publishing Limited.

Dechow, P. M. \& Dichev, I. (2002). The quality of accruals and earnings: The role of accrual estimation errors. Accounting Review, 77, 35-59. https://doi.org/10.2308/accr.2002.77.s-1.35

Dechow, P. M., Kothari, S. P. \& L. Watts, R. (1998). The relation between earnings and cash flows. Journal of Accounting and Economics, 25(2), 133-168. https://doi.org/10.1016/S0165-4101(98)00020-2

Dechow, P. M., Richardson, S. A., \& Tuna, I. (2003). Why are earnings kinky? An examination of the earnings management explanation. Review of Accounting Studies, 8(2), 355-384. https://doi.org/10.1023/a:1024481916719

Dechow, P. M., Sloan, R., \& Sweeney, A. (1996). Causes and consequences of earnings manipulation: An analysis of firm subject to enforcement actions by the SEC. Contemporary Accounting Research, 13(1), 1-36. https:// doi.org/10.1111/j.1911-3846.1996.tb00489.x

Djankov, S., laPorta, R., Lopez-De-Silanes, F., \& Shleifer, A. (2008). The law and economics of self-dealing. Journal of Financial Economics, 88(3), 430-465. https://doi.org/10.1016/j.jfineco.2007.02.007

Durtschi, C., \& Easton, P. (2009). Earnings management? Erroneous inferences based on earning frequency distribution. Review of Accounting Studies, 47(5), 1249-1281. https://doi.org/10.1111/j.1475-679X.2009.00347.x

Francis, J., Schipper, K., \& Vincent, L. (2005). Earnings and dividend informativeness when cash flow rights are separated from voting rights. Journal of Accounting and Economics, 39(2), 329-360. https://doi.org/10.1016/j. jacceco.2005.01.001

Goergen, M., Limbach, P., \& Scholz, M. (2015). Mind the gap: The age dissimilarity between the chair and the CEO. Journal of Corporate Finance, 35, 136-158. https://doi.org/10.1016/j.jcorpfin.2015.08.011

Gormley, T., \& Matsa, D. (2014). Common errors: How to (and not to) control for unobserved heterogeneity. Review of Financial Studies, 27(2), 617-661. https://doi.org/10.1093/rfs/hht04

Gómez-Mejía, L. R., Cruz, C., Berrone, P., \& de Castro, J. (2011). The bind that ties: Socioemotional wealth preservation in family firms. The Academy of Management Annals, 5(1), 653-707. https://doi.org/10.5465/ 19416520.2011 .593320

Gómez-Mejía, L. R., Haynes, K. T., Núñez-Nickel, M., Jacobson, K. J., \& Moyano-Fuentes, J. (2007). Socioemotional wealth and business risks in family-controlled firms: Evidence from Spanish olive oil mills. Administrative Science Quarterly, 52(1), 106-137. https://doi.org/10.2189/asqu.52.1.106

Hayn, C. (1995). The information content of losses. Journal of Accounting and Economics 20, 125-153.

Hazarika, S., Karpoff, J. M., \& Nahata, R. (2012). Internal corporate governance, CEO turnover, and earnings management. Journal of Financial Economics, 104(1), 44-69. https://doi.org/10.1016/j. jfineco.2011.10.011 
Healy, P. M., \& Wahlen, J. M. (1999). A review of the earnings management literature and its implications for standard setting. Accounting Horizons, 13(4), 365-383. https://doi.org/10.2308/acch.1999.13.4.365

Hou, Q., Jin, Q., Yang, R., Yuan, H. \& Zhang, G. (2015). Performance commitments of controlling shareholders and earnings management. Contemporary Accounting Research, 32(3), 1099-1127. https://doi.org/10.1111/ 1911-3846.12111

Jiang, J. X., Petroni, K. R. and Wang, I. Y. (2010). CFOs and CEOs: Who have the most influence on earnings management? Journal of Financial Economics, 96(3), 513-526. https://doi.org/10.1016/j. jfineco.2010.02.007

Jones, J. J. (1991). Earnings management during import relief investigations. Journal of Accounting Research, 29(2), 193-228. https://doi.org/10.2307/2491047

Kaplan, S. N., \& Minton, B. A. (2012). How has CEO turnover changed? International Review of Finance, 12(1), 57-87. https://doi.org/10.1111/j.1468-2443.2011.01135.x

Leuz, C., Nanda, D., \& Wysocki, P. D. (2003). Earnings management and investor protection: an international comparison. Journal of Financial Economics, 69(3), 505-527. https://doi.org/10.1016/ S0304-405X(03)00121-1

Martin, G., Campbell, J. T., \& Gomez-Mejia, L. (2016). Family control, socioemotional wealth and earnings management in publicly traded firms. Journal of Business Ethics, 133(3), 453-469. https://doi.org/10.1007/ s10551-014-2403-5

Nobes, C. (2011). International variations in IFRS adoption and practice (Research Report 124). Certified Accountants Educational Trust, Association of Chartered Certified Accountants.

La Porta, R., Lopez-de-Silanes, F., Shleifer, A., \& Vishny, R. W. (1997). Legal determinants of external finance. Journal of Finance, 52(3), 1131-1150. https://doi.org/10.1111/j.1540-6261.1997.tb02727.x

La Porta, R., Lopez-de-Silanes, F., Shleifer, A., \& Vishny, R. W. (1998). Law and finance. Journal of Political Economics, 106(6), 1113-1155. https://doi.org/10.1086/250042

Rosenbaum, P. R., \& Rubin, D. B. (1983). The central role of the propensity score in observational studies for causal effects. Biometrika, 70(1), 41-55. https://doi.org/10.1093/biomet/70.1.41

Roychowdhury, S. (2006). Earnings management through real activities manipulation. Journal of Accounting and Economics, 42(3), 335-370. https://doi.org/10.1016/j.jacceco.2006.01.002

Wang, D. (2006). Founding family ownership and earnings quality. Journal of Accounting Research, 44(3), 619-656. https://doi.org/10.1111/j.1475-679X.2006.00213.x

\section{SUPPORTING INFORMATION}

Additional supporting information may be found online in the Supporting Information section.

How to cite this article: Ansari, I. F., Goergen, M., \& Mira, S. (2021). Earnings management around founder CEO reappointments and successions in family firms. European Financial Management, 1-34. https://doi.org/10.1111/eufm.12307

\section{APPENDIX 1: SAMPLE SELECTION}

This table reports the sample selection in detail. We start with the full population of firms listed in France, Germany and the United Kingdom from 2001 to 2016, which comprises 2,679 French firms, 2,352 German firms and 7,774 UK firms. However, as we look at earnings management 2 years around the event, effectively our sample spans from 1999 to 2018. We then exclude the financial firms (with an ICB code of 8000), firms with their preference shares listed only and missing total assets for all 16 years of the study. This sample is then used to estimate the 
measures of earnings management discussed in Section 3.2. Next, we identify the family firms in the sample. A family firm is defined as a firm with an incumbent family CEO as well as with a family owning at least $25 \%$ of the votes and remaining the largest shareholder for at least half of the period of the study. We retain only those family firms with at least one change in the CEO or at least one reappointment of the incumbent CEO during 2001 and 2016. Finally, after dropping the firms without a clear-cut succession date (i.e., those firms whose annual reports suggest there was a change of the CEO in a particular year, but we are unable to identify the exact succession date), we end up with a final sample of 240 family firms. Out of the 240 firms 122 are French firms, 76 are German and the remaining 42 are UK firms.

\begin{tabular}{|c|c|c|c|}
\hline Criteria & France & Germany & $\begin{array}{l}\text { United } \\
\text { Kingdom }\end{array}$ \\
\hline Full population of listed firms from 2001 to 2016 & 2,679 & 2,352 & 7,747 \\
\hline Total firms excluded from the sample & $-1,800$ & $-1,863$ & $-4,687$ \\
\hline \multicolumn{4}{|l|}{ Of which } \\
\hline Financial firms (ICB code 8000) & 415 & 554 & 1,092 \\
\hline Firms with preference shares only & 1 & 40 & 0 \\
\hline Missing total assets for all 16 years & 1,384 & 1,269 & 3,568 \\
\hline $\begin{array}{l}\text { Remaining population which is used to estimate earnings } \\
\text { management }\end{array}$ & 879 & 489 & 3,087 \\
\hline $\begin{array}{l}\text { Select from the above remaining population family } \\
\text { firms only }\end{array}$ & 187 & 120 & 87 \\
\hline $\begin{array}{l}\text { Family firms with at least one change or reappointment } \\
\text { in CEO }\end{array}$ & 125 & 80 & 42 \\
\hline Dropping firms with missing clear-cut succession date & -3 & -4 & 0 \\
\hline \multicolumn{4}{|l|}{ Firms in the final sample } \\
\hline Family firms & 122 & 76 & 42 \\
\hline \multicolumn{4}{|l|}{ Events in the final sample } \\
\hline Family firms & 152 & 95 & 59 \\
\hline
\end{tabular}




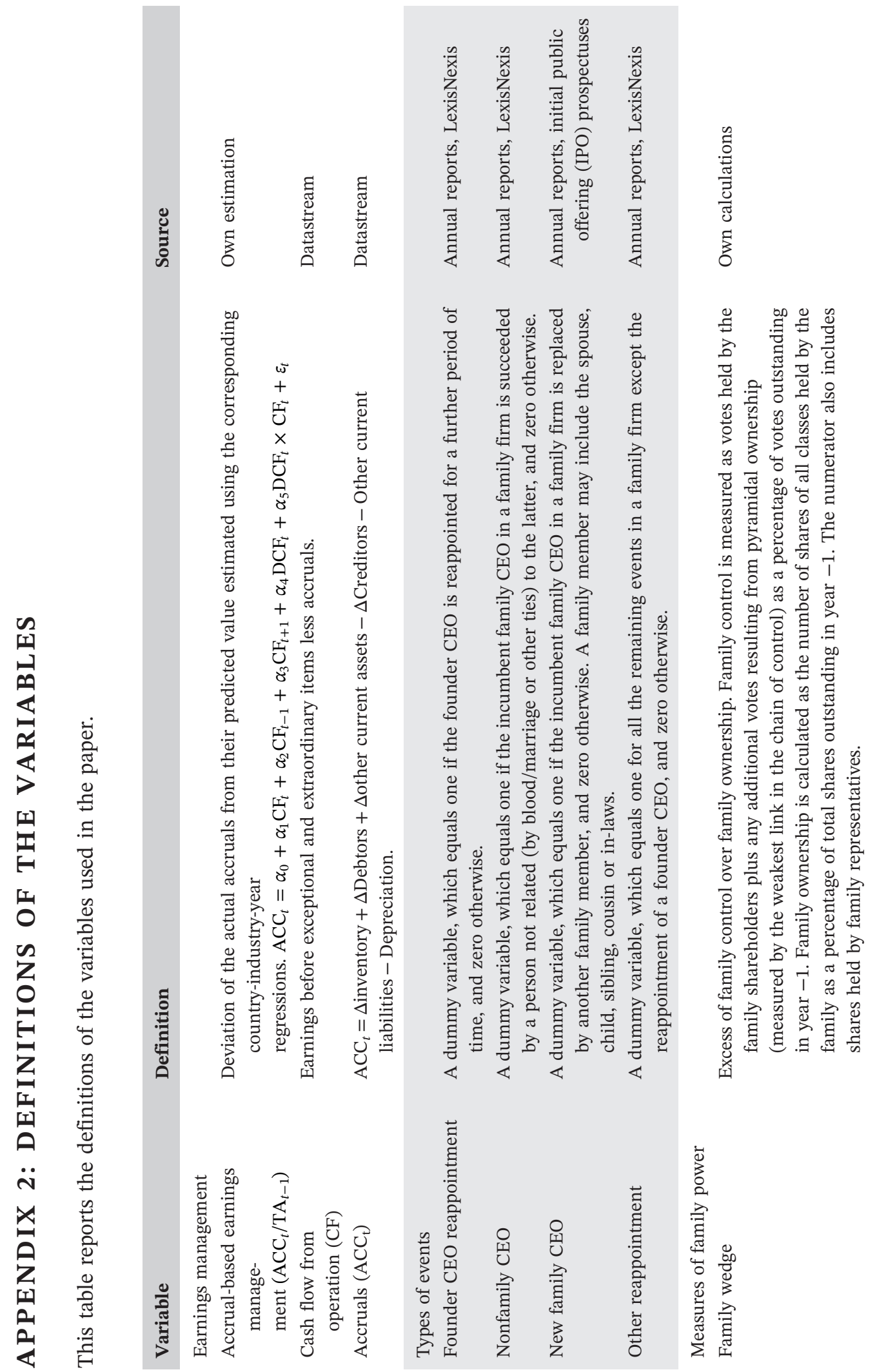


$\stackrel{\circ}{\circ}$

㝕

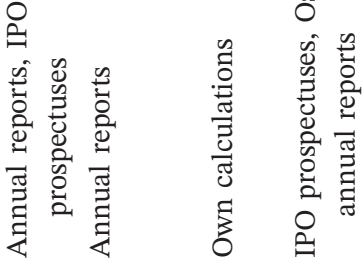

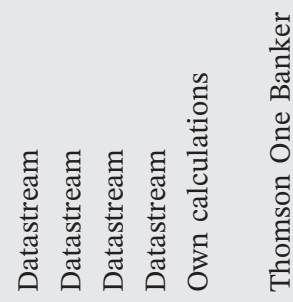

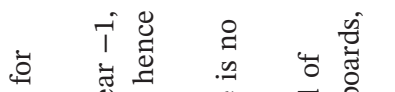

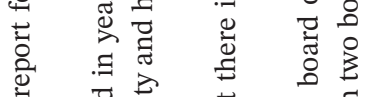

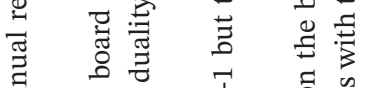

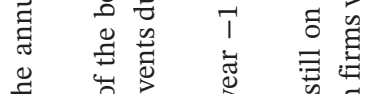

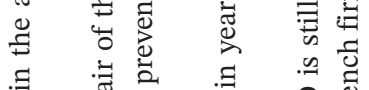

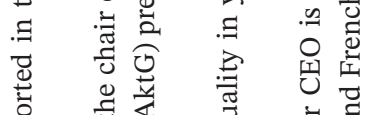

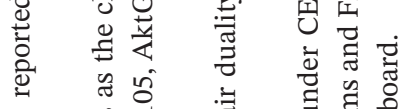

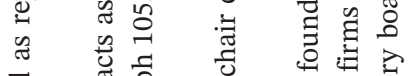

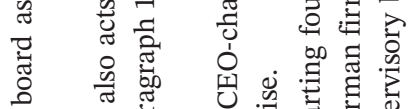

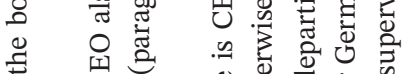

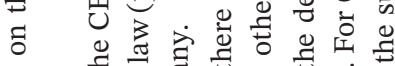

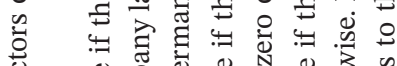

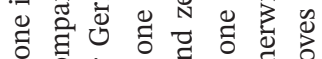

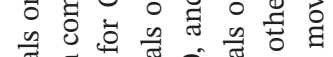

䒕泀

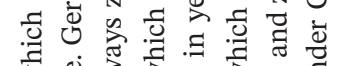

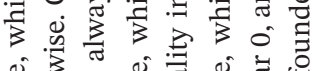

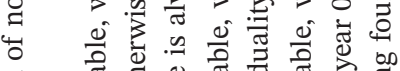

葛

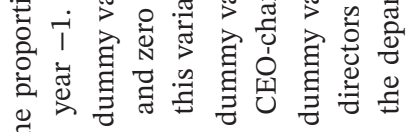

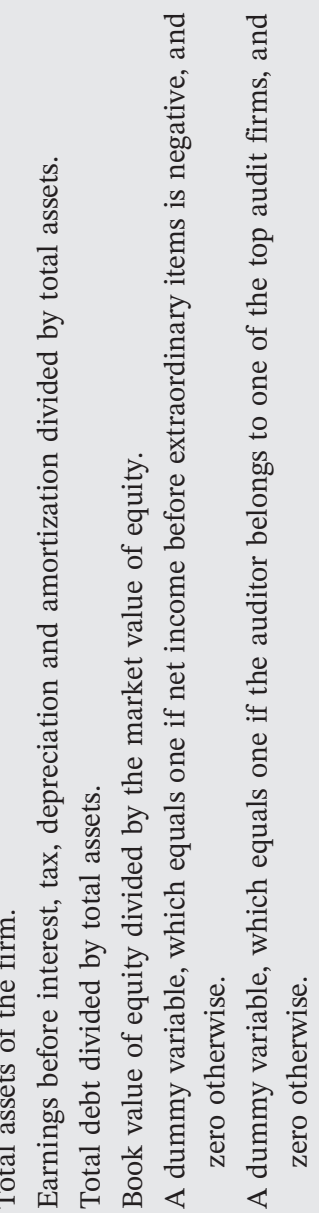

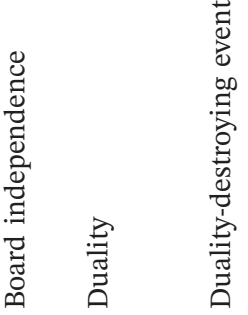

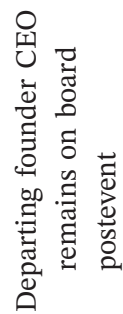

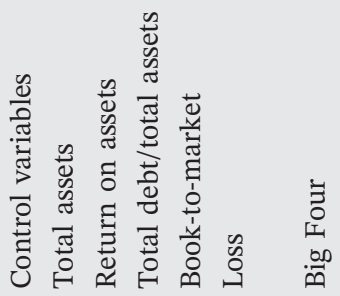

